Portland State University

PDXScholar

7-2-1997

\title{
Hiroshima mon amour and L'Annee derniere a Marienbad: Meaning Conveyed through Cinematic Organization
}

Ellen Leigh Agee

Portland State University

Follow this and additional works at: https://pdxscholar.library.pdx.edu/open_access_etds

Part of the French and Francophone Language and Literature Commons Let us know how access to this document benefits you.

Recommended Citation

Agee, Ellen Leigh, "Hiroshima mon amour and L'Annee derniere a Marienbad: Meaning Conveyed through Cinematic Organization" (1997). Dissertations and Theses. Paper 5210.

https://doi.org/10.15760/etd.7086

This Thesis is brought to you for free and open access. It has been accepted for inclusion in Dissertations and Theses by an authorized administrator of PDXScholar. Please contact us if we can make this document more accessible: pdxscholar@pdx.edu. 
The abstract and thesis of Ellen Leigh Agee for the Master of Arts in French were presented July 2, 1997, and accepted by the thesis committee and the department.

COMMITTEE APPROVALS:
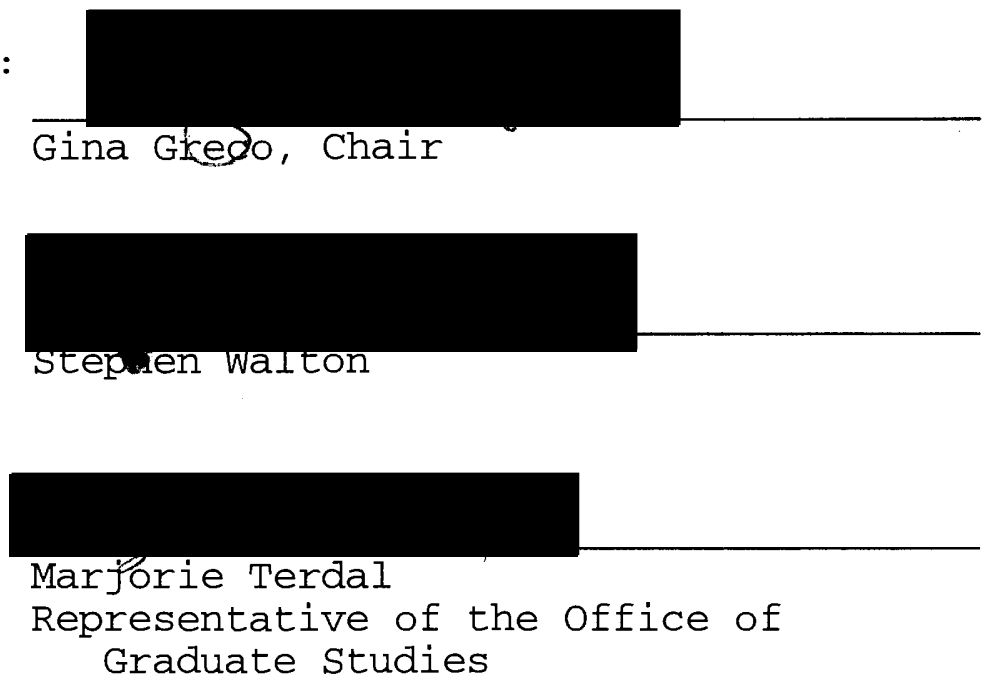

DEPARTMENT APPROVAL:

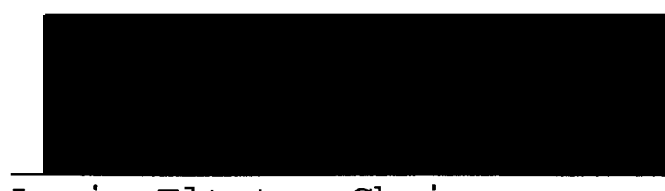

Louis Elteto, Chair

Department of Foreign Languages and Literatures

\section{ACCEPTED FOR PORTLAND STATE UNIVERSITY BY THE LIBRARY}

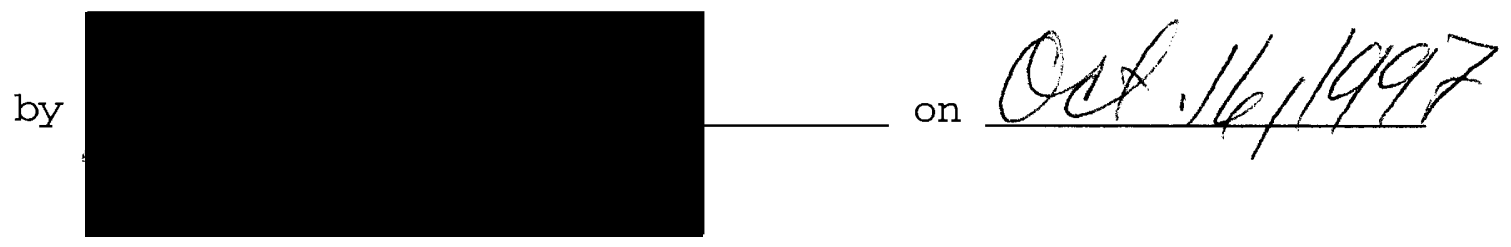




\section{ABSTRACT}

An abstract of the thesis of Ellen Leigh Agee for the Master of Arts in French presented July 2, 1997.

Title:

Hiroshima mon amour and $\mathrm{L}^{\prime}$ Année dernière à Marienbad: Meaning Conveyed Through Cinematic Organization.

This thesis examines how the cinematic organization of film is used to convey meaning. Hiroshima mon amour (1959) and L'Année dernière à Marienbad (1961), two films directed by Alain Resnais, are used as models for this purpose. This thesis argues for a new type of film criticism, one that recognizes the uniqueness of film by adding technical analysis to the literary methods that currently dominate.

Traditionally, film criticism has followed two directions: firstly that of the "film reviewer" whose efforts bow to the economic needs of the industry, and secondly the academic or scholarly approach which is based in large part on literary criticism, and falls into 
two general categories, thematic analysis and interpretive analysis.

This thesis proposes that the literary methods which are appropriate for literature are inadequate for film, because of the way cinematographic technique is employed to convey meaning. To this end, the films, Hiroshima mon amour and I'Année dernière à Marienbad, are analyzed in terms of technique and how technique structures film, as well as in more traditional terms.

The evolution of film technology correlates directly with what a director is able to portray on the screen, and so it is appropriate to include in this examination the art-historical context of Hiroshima, mon amour and L'Année dernière à Marienbad: what came directly before as well as what was happening in literature, art, politics and film technology contemporaneously with these two films.

The organization of film not only occurs at a literary or intellectual level, but at a physical or technical level. The intent of this thesis is to implement a model for a third sort of film analysis, an alternative to interpretation-driven criticism, one which 
includes, in addition to explication and interpretation, the use of film technology as a valid means of comprehending a film. The result of this broader form of analysis is a more accurate understanding of film through the comprehension of the aspects which make it an original art form. The use of specific film technology forms a more balanced and accurate approach to film criticism. 
HIROSHIMA MON AMOUR AND L'ANNEE DERNIERE A MARIENBAD:

MEANING CONVEYED THROUGH CINEMATIC ORGANIZATION

by

ELLEN LEIGH AGEE

A thesis submitted in partial fulfillment of the requirements for the degree of

\author{
MASTER OF ARTS \\ in \\ FRENCH
}

Portland State University

1997 


\section{TABLE OF CONTENTS}

I. Introduction.................... 1

II. Historical context................ 12

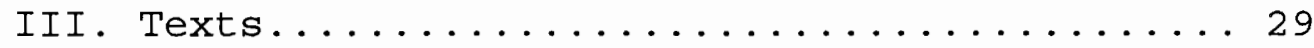

IV. Themes, Plots and Intentions........... 54

V. Technology.................... 80

VI. Conclusion..................... 116

VII. Bibliography and Filmography.......... 126 
CHAPTER I - INTRODUCTION

This thesis analyzes Hiroshima mon amour (1959) and L'Année dernière à Marienbad (1961), two films directed by Alain Resnais, with scripts written respectively by Marguerite Duras and Alain Robbe-Grillet. It examines how the cinematic organization of these films is used to convey meaning. The purpose of this introduction is to establish a context for the examination of the cinematic organization of these two films. To accomplish this I offer a brief overview of the genre of film criticism. Ultimately, I argue for a new type of film criticism, one that recognizes the uniqueness of film by adding technical analysis to the modes of analysis that currently predominate, modes which are borrowed directly from literary criticism.

In Making Meaning, film theorist and historian David Bordwell analyzes current film criticism, and argues for the need for a new approach to film analysis. Traditionally film criticism has followed two directions. First, there is the 'film reviewer' whose efforts support 
the needs of the industry. Typically, the film review consists of four parts: a plot synopsis, background information, a series of arguments for and/or against the film, and finally a judgment or recommendation. ${ }^{1}$ second, there is the academic or scholarly approach, which is based in large part on literary criticism, and which falls into two general categories: the explication of the text's explicit meaning or manifest content, and the interpretation of the text's implicit meaning or latent content. One of the goals of explicatory criticism is to establish that a given art form, whether it be literature or film, has societal value. Explication accomplishes this goal through its consideration of archetypal themes, and its examination of individual experience in terms of human values. Explication formed the basis of film criticism until the 1970's, but with the end of the avant-garde cinema, interpretive criticism arrived, dominating the

1 David Bordwell, Making Meaning: Influence and Rhetoric in the Interpretation of Cinema (Cambridge: Harvard UP, 1989) 38. 
field from that point forward. ${ }^{2}$

In film, as in literature, the interpretation of latent content can take one of two directions: it can focus on the director or writer and his personal obsessions, or on the society that has formed him, as seen in terms of the politics or ideology underlying the film or text. Thus traditional film theory, like literary theory, uses explication and interpretation as its major tools.

Bordwell sees existing criticism as being built upon distinct processes: the crafting of critical arguments, that is, building analogies, picking out relevant passages or scenes, and then arranging these arguments in an appealing order. ${ }^{3}$ Texts and films offer the reader and viewer the opportunity to engage in certain activities involving perception, cognition, and emotion. This is possible because inherent in the structure of a text or film are certain attributes which act as cues, setting in

2 Bordwell, Making Meaning preface xiil.

3 Bordwell, Making Meaning 37-38. 
motion or triggering certain responses. In order to assign meanings to these cues, whether explicit or implicit, the critic must bring to his work some particular hypothesis. The success of such an endeavor is dependent upon the appropriateness of the hypothesis, how the data fits the theory, the novelty of the hypothesis, and its plausibility and persuasiveness. ${ }^{4}$

Bordwell further asserts that typical film interpretation follows the plan for theater laid down by Aristotle and later revised by Cicero, which consists of the following: an introduction, followed by the background, which in film interpretation is a brief account of the issue's history or a synopsis of the film, then a statement of the thesis to be proven; next comes the body of the text consisting of a breakdown of the points that support the thesis, followed by arguments favoring each point and the destruction of opposing arguments; lastly, the conclusion which is a review and a

4 Bordwe11, Making Meaning 29-30. 
persuasion. ${ }^{5}$

However, the organization of a film not only occurs at a literary or intellectual level, but also at a physical or technical level. The intent of this thesis is to implement a model for a third sort of film analysis, an alternative to interpretation-driven criticism, one which includes, in addition to explication and interpretation, the use of film technology as a valid means of comprehending a film. There is an art to understanding or comprehending a film, and another to explaining or interpreting it. ${ }^{6}$ Film techniques create certain emotional and psychological responses in the viewer. Meaning itself is just one aspect of film, but through film technology and its organization one can begin to distinguish different kinds of meaning. Bordwell makes an argument in favor of a different sort of film criticism. He speaks in terms of effects and functions and composition. He argues against the major role that the

5 Bordwell, Making Meaning 212-213.

${ }^{6}$ Bordwell, Making Meaning 2 . 
interpretation of implied material plays in criticism, and stresses a need to acknowledge phenomenal qualities, which are often played down, or overlooked in conventional criticism. He insists upon "different sorts of meaning, at different levels of concreteness" 7 as well as the need to place a work of art in its historical context. He also makes an argument for the necessity of studying the concrete technical activities that are involved in filmmaking, the filmmaker's craft, with their resulting perceptual, cognitive, and emotional responses. This thesis implements some of these suggestions in analyzing the two films.

Historically, the evolution of film technology correlates directly to what a director is able to portray on the screen, and this technology as well as the film content is the product of a particular period in history. For this reason it seems appropriate to include in this examination the art-historical context of the films under consideration: what came directly before them, as well as

7 Bordwell, Making Meaning 264 . 
what was happening contemporaneously in literature, art, politics and technology. Also, the historical context not only catalogues the technology available at any given period but dictates audience response to film technique. This is because the viewer adjusts his perception relative to what he has previously seen. Thus there is an historical context to viewer interpretation, which evolves alongside, at a pace with technical development.

The result of this broader form of analysis is a more accurate understanding of film through the comprehension of the aspects which make it an original art form. In her essay, "Against Interpretation," Susan Sontag states, "The function of criticism should be to show how it is what it is, even that it is what it is rather than to show what it means." ${ }^{8}$ The emphasis is hers.

My application of this broader form of analysis is organized as follows: Chapter two introduces the art-historical context of the films: two trends in

8 Susan Sontag, "Against Interpretation," The Rhetoric of Film. ed. John Harrington, (New York: Holt, Rinehart and Winston, 1973) 364. 
literature, le nouveau roman and le ciné-roman; the influences of literature on film as seen in the concepts of I'écriture cinématographique, la politique des auteurs and le caméra-stylo; trends in filmmaking including the art-film, the experimental film and la nouvelle vague; changes in the role of the spectator; and finally the impact of modernism and the effects of life in postwar France. This chapter concentrates on the origins and history of these trends and movements, and the qualities or characteristics which define them.

Chapter three examines the two texts of Hiroshima mon amour and L'Année dernière à Marienbad, as sub-structure for the films, and as representative examples of literature of the period, underlining the differences between authors' approaches and the uses to which Resnais puts the texts.

Chapter four explores Resnais's intentions toward the viewer as seen in the films' themes, and in the development of content. The films' themes are considered in terms of psychology, ethics, politics, religion and 
emotion. Film content is examined in terms of plot development, action, character, conflict and Resnais's personal aesthetic. Finally, and most importantly, this chapter demonstrates how theme and content reflect the director's intentions toward the viewer. At their best Resnais's films teach the viewer to see, to participate and to question the veracity of images and history. Ultimately, his films show us our inability to relate to the experiences of others or even to remember accurately our own past.

Chapter five contains the body of the thesis. In this chapter, I examine how Resnais employs film technique to convey specific meanings to the viewer. I analyze the structure of the films, first in terms of the image: the frames, shots, scenes and sequences that make up the physical reality of the film, as well as the specific technical use of the camera for close-up and deep-focus work. Types of footage are discussed, fictional and documentary, cinéma vêrité, as well as the use of the negative image. I look at the camera as narrator, the 
protagonist as narrator, space and spatial relationships, mise en scène and montage, editing and linking. Next, the discussion moves to the films' texts and sub-texts. Here the focus is on dialogue, description, voice-over and interior monologue. I examine the use of non-linear narratives, which reflect modernist trends, in terms of unexplained events, the lack of conclusion or moral judgment, and the use of poetic narrative. Third, sound is analyzed, including voices, music, sound effects and silence. Sound is also discussed in terms of volume, actual sound, commentative sound, contrapuntal sound, asynchronous sound and ambient sound. Fourth, the focus shifts to the aspects of time observed in the films. These aspects consist of memory, remembering and forgetting, real time, psychological time and dramatic time. Finally, I will examine the role of repetition as a structuring mechanism in the two films.

Chapter six concludes with an evaluation of this method of looking at film: how the inclusion of arthistorical content and the use of specific film technology 
form a more balanced and accurate approach to film criticism. 


\section{CHAPTER II - HISTORICAL CONTEXT}

Hiroshima mon amour and L'Année dernière à Marienbad can be classified variously as 'art cinema' and 'experimental cinema' as well as 'postwar cinema.' Art cinema is the term used to describe films made commercially, whose approach to form and style are influenced by modernist trends in art, rather than typical Hollywood formulas. Experimental cinema, on the other hand, seeks to explore unusual aspects of the medium itself, including film technology, and often uses controversial subject matter. The plots of experimental films, when they do employ plots, are often based upon dreams, symbolic journeys or quests. However these films frequently avoid any sort of narrative, exploring instead lyrical or poetic approaches or other forms of expression such as associational or descriptive filmmaking. Associational filmmaking refers to films where the viewer must make the connections, the associations between past and present, different story lines, characters and images, fragmented narrative and cryptic dialogue. In this case it 
is the viewer who does the work, unravels the mystery. Descriptive filmmaking gives a dense surface of information without necessarily revealing the underpinnings of the film. Both art cinema and experimental cinema shy away from conventional approaches, offering alternatives to mainstream filmmaking. Postwar cinema refers generaliy to all film trends occurring after World War II. Postwar cinema picked up the threads of the modernist movement that had existed prior to the second World War and following World War I. The postwar art film marks a return to the modernist impulses, as seen in French Impressionism (1920-1923), Surrealism (1924-1930), German Expressionism (1920-1927) and Soviet Montage(19251933).

In France, for a variety of reasons, the shift from wartime styles to other genres proceeded slowly. Economics was one reason for the delay. Banks backed conventional filmmaking and proven directors rather than risking money on new filmmakers with new ideas. Another reason for the delay was the hesitancy of filmmakers themselves to 
abandon the familiar, secure conventions that had sustained the industry throughout the war and the occupation. This style of wartime filmmaking, which became known as la tradition de qualité, dominated French cinema in the decade following the war. It was also referred to as le cinéma du papa to designate its oldfashioned status. These films consisted of fantasy and escapist themes, literary and historical subjects, and costume dramas that were shot almost entirely on closed studio sets.

In France, the repression of the Occupation, and the deprivation of visual images, particularly in the realm of cinema, resulted in a renewed interest in film and in an outpouring of film theory after the war. This new film theory was developing in opposition to la tradition de qualité, and its prime movers were the writers and critics of the French film journal, "Cahiers du cinéma," launched in April 1951. Starved for filmic representation, the French welcomed the flood of American films, years' worth, that reached France after the liberation. The arguments 
that ensued did not question film as art, but rather debated the idea of which art form film resembled more, the theater or the novel. The ideas explored in this period have permanently shaped film theory and filmmaking, and were responsible for the birth of la nouvelle vague in the late 1950s. But film theory and filmmaking are two very different things, and in France, the making of contemporary films lagged behind contemporary theory.

As previously stated, postwar French cinema was the domain of la tradition de qualité where the adaptation of literary classics predominated, and the scriptwriter was king. Directors were reduced to little more than metteurs en scène with a style that was a continuation of the approach established during the Occupation. These films depended more on mis en scène than on montage; they were literally bound to the studio.

But this same conservative postwar French film industry had as its financial basis, a system of funding, that was to provide the means for the film experimentation to come. Unlike the film industry in the United States, 
which at the time was comprised of a few large controlling production companies, the French film industry consisted of smaller more artisanal production companies which allowed greater diversity, and more experimentation in terms of form and style. In 1953, changes in French law encouraged the production of short documentary films by making production money for such projects more readily available, through state subsidies as well as bank loans. Several directors got their start in this way, among them

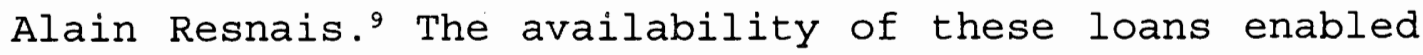
directors to experiment with modernist ideas which ultimately led to la nouvelle vague. Resnais and his films were a product of this modernist trend, and although he was firmly established in the film industry before the arrival on the scene of la nouvelle vague, his rise to fame coincided with and affected this movement.

The effects of a return to modernism differed from

${ }^{9}$ Kristin Thompson and David Bordwell, Film History: An Introduction. (New York. McGraw-Hill, 1976) $434-444$. 
country to country and from culture to culture. In France it created la nouvelle vague in film. This movement born out of the French postwar intellectual ferment, embraced film as an art form, and rebelled against the classical tradition. Originally the term nouvelle vague did not refer to cinema at all, but to the young postwar generation which was to bring new ideas into French political life. In 1958, l'Express's specialist on youth, Françoise Giroud, titled an article "La Nouvelle Vague" in which she changed the connotation of the phrase to mean 'the new fashion.'10 La nouvelle vague (1958-1965) heralded a return to modernism in film as the nouveau roman and ciné-roman dià in literature.

The nouveau roman and the ciné-roman originated in France in the late 1950 s and Alain Robbe-Grillet was one of the principal writers associated with these literary movements. The nouveau roman attempted to disassociate itself from traditional narrative form, and from the idea

10 John Francis Kreidel, Alain Resnais (Boston: Twayne, 1977) 82 . 
that literature was representative of life. It challenged the assumption that "art imitates life." It suggested rather that narrative was a set of artificial devices imposed on readers by authors, and that readers had become accustomed to these narrative conventions. The writers of the nouveau roman made visible the structure of the novel, and suggested that the structure, and the means of producing it, were what the novel was in reality. Thus in effect the novel was about the art of writing, not about narrative or representing reality. The ciné-roman carried this position to the next logical step in relationship to the film script. Just as the nouveau roman was considered as the structure of the novel, so the ciné-roman, or film script, was the structure of a film. Normally the film script disappeared, was abscrbed by the film. In the case of the ciné-roman, however, it was again the structure, the means that were made visible and deemed important, rather than the end product.

With these changes in the text the role of the reader shifted. "He or she is called upon to co-author the text, 
to act not as a passive recipient of information, but as an active producer of meaning."11 The reader searches for meaning, but the narrative is so fragmented, and gives such limited and often conflicting information, that many different interpretations are possible and none are conclusive. This shift in reader responsibility is pivotal in terms of viewing new film genres and is extensively discussed later in this thesis.

Like the nouveau roman and the ciné-roman, the nouvelle vague became known for certain stylistic and thematic features originating from modernist thought and adapted to film. Modernism definitively influenced twentieth-century film, as much as it did the art and literature of the period. It places the emphasis on aesthetic innovation and on themes which comment upon contemporary life. Modern society was influenced by the second World war and its aftermath, and by the technological advances born of wartime necessity. These

"Marion Wynne-Davies, ed. The Bloomsbury Guide to English Literature (New York: Prentice Hall General Reference, 1990) 775. 
influences, which manifested themselves as fragmentation and a tendency toward chaos, were visible in contemporary art as well as the daily life of postwar industrialized nations. The modernist trend in art displays difficult, often aggressive or disruptive forms and styles, frequently challenging traditional art forms and criticizing norms. The Bloomsbury Guide to English Literature says of the modernist movement:

Since the term 'modernism' was first used earlier in the $20^{\text {th }}$ century, its meaning has been developed and revised. It is now agreed to mean the influential international movement in literature, drama, art, music and architecture which began in the later years of the $19^{\text {th }}$ century and flourished until at least the 1920s. Modernism was felt to be a reaction to Realism and Naturalism, undermining the representation associated with those movements. ${ }^{12}$

Modernism challenged the existing approaches of the late

12 Wynne-Davies 724 . 
nineteenth century and laid the groundwork for its later development in the mid-twentieth century. It used both political criticism and spiritual exploration as tools, and gave rise to both Expressionism and Surrealism. Common themes involved technology, urban life and personal identity. These thematic devices were readily apparent in film: alienated youth, manic city dwellers, young people leading confused lives, and directors' varied personal visions tempered by tragedy or comedy.

Postwar modernism in filmmaking can also be defined by certain stylistic, technical and formal features, rather than relying solely on thematic ones. First of all, filmmakers attempted to be more true to life, more realistic than most wartime classical filmmakers were seen to be, and they employed objective realism which avoided tightly structured plots. Film theorist siegfried Kracauer explained that film "is uniquely equipped to record and reveal physical reality and, hence, gravitates toward 
it."13 In addition European postwar films favored openended narratives, in which central plot lines were left unresolved. Stylistically, modernistic filmmakers came to rely on the long take, sustained by camera movement, on deep-focus shooting and deep-space staging of scenes. They employed a fluidity in editing, narrative flow and language, and made extensive use of the hand-held camera and the wide screen, and they also tended to present events in real time. Film represents "reality as it evolves in time."14 New acting styles appeared which were more like real life and less like glossy Hollywood productions, featuring more halting delivery, fragmented speech, and a lack of eye contact between players. Kracauer urged "that the best use of film is an honest reliance on its capacity to convey authenticity, to preserve and celebrate the sense of reality."15 And this in essence is what the new avant-

${ }^{13}$ Siegfried Kracauer, Theory of Film: The Redemption of Physical Reality (New York: Oxford UP, 1960) 28 .

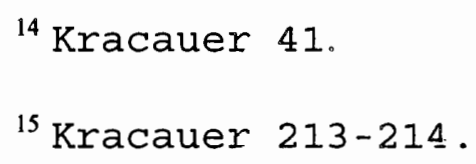

${ }^{14}$ Kracauer 41.

${ }^{15}$ Kracauer 213-214. 
garde attempted to do.

Hand in hand with objective realism came subjective realism, or the psychological forces behind individual behavior. Flashback construction became a common means for exploring history in a personal way. Authorial commentary came into its own, the director openly using film as a personal forum, and as a result "the problem of portraying an attitude toward the thing portrayed"16 became an ethical consideration. This authorial commentary and the portraying of a personal vision combined with an obvious cinematographic style became known as la politique des auteurs.

La politique des auteurs developed in part as a reaction to the rigidity in form and content seen in French filmmaking during the Occupation and after the war. Instrumental in forming la politique des auteurs was the article entitled "The Birth of a New Avant-Garde: Le Caméra-Stylo" published in "l'Écran français" in 1948 by French director and film theorist, Alexandre Austruc. This

${ }^{16}$ Kracauer 150 . 
article spoke of the camera-stylo in terms of film direction, predicting that directors would be able to use the cinema as a personal form of expression, that cinematic expression would become as fluid, as flexible as a writer and his pen:

...the cinema will gradually break free from the tyranny of what is visual, from the image for its own sake, from the immediate and concrete demands of the narrative, to become a means of writing just as flexible and subtle as written language. ${ }^{17}$

This distinction between caméra-stylo and scripting and shooting a film in factory-fashion has a fundamental methodological difference: in the former case the film becomes a tight extension of the thinking of the author, his 'writing.' In the second case the film is 'made as a product. ${ }^{\prime 18}$

17 Alexandre Astruc, "The Birth of a New AvantGarde: La caméra-stylo," The New Wave. ed. Peter Graham (New York: Doubleday, 1968) 18.

${ }^{18}$ Kreidel 40. 
François Truffaut first defined la politique des auteurs in an article for "Cahiers du Cinema" entitled "Une certaine tendance du cinéma francais," on New Year's Day, 1954, and this premise became the creed for the underlying structure of new wave films. The essence of this theory has been presented by Anthony N. Fragola and Roch C. Smith in The Erotic Dream Machine, a series of interviews with writer-director, Alain Robbe-Grillet. He argues: "The body of an auteur's films should be studied in light of recurring techniques, themes and the discernible personality of the director."19 Robbe-Grillet insists that in a body of work, a director must exhibit certain recurring characteristics of style, which serve as his signature. American film theorist Andrew Sarris concurs: "The way a film looks and moves should have some relationship to the way a director thinks and feels."20

${ }^{19}$ Anthony N. Fragola and Roch C. Smith, The Erotic Dream Machine (Carbondale: Southern Illinois UP, 1992) 4 .

${ }^{20}$ Andrew Sarris, "Notes on the Auteur Theory in 1962," Perspectives on the study of Film, ed. John Stuart Katz (Boston: Little Brown, 1971) 512. 
According to Sarris, the premises of the auteur theory may be visualized as three concentric circles: the outer circle, as technique; the middle circle, as personal style; and the inner circle, as interior meaning. The corresponding roles of the director may be designated as those of a technician, a stylist, and an auteur. ${ }^{21}$ In addition to assigning a new, more extensive role to the director of a film, this new approach assigned additional responsibilities to the viewer as well, not unlike the role of the reader of the nouveau roman. Structuring films to force viewer participation was a major task of new wave directors.

Film has limitations in its ability to lead viewers to an idea. Preconceptions generally govern how people see, determining responses to cinematic images. Although the director does most of the work on the film, the viewer must use his inteliect, his imagination and his senses in viewing a film. Active participation in the process of comprehending a film demands that the viewer confront some

${ }^{21}$ Sarris 513. 
part of himself or the world. In an interview with Alain Resnais in Le Monde in 1962, reporter Yvonne Baby elicited the filmmaker's response on the subject: "The film is so made that fifty percent of it is what is shown there on the screen and the rest [comes from] the reactions and the participation of the spectator." ${ }^{22}$ Cinematic representation cues the spectator to engage in a variety of learned behaviors that aid in creating a story from the material presented. The reactions and participation of the viewer are based on such factors as background knowledge, previous film-viewing experience, problem-solving processes and other cognitive operations. In terms of cinema, perceiving and thinking are considered active goal-oriented processes, which exist simultaneously during the viewing of a film. Thus, individually, "perception becomes a process of active hypothesis-testing," ${ }^{23}$ not just a passive occupation but a purposeful activity involving shared knowledge, visual memory, expectations and emotions. This active

22 Kreidel 79.

${ }^{23}$ David Bordwell, Narration in the Fiction Film (Madison: U of Wisconsin P, 1985) 31. 
participation of the viewer is a fundamental part of the postwar movie experience, and is one of the elements considered by the director in designing a film. He realizes that skill in story comprehension is acquired and cumulative and that the evolution of how the viewer experiences and understands film are intimately tied to film technology. 


\section{CHAPTER III - TEXTS}

Jean-Claude Carrière, celebrated French screenwriter, speaks of the relationship of text to film: "I fail to see how you can dissociate a screenplay from a film, appreciate them separately... A film is always a thing in itself, a more or less successfully executed whole..."24 $\mathrm{He}$ continues: "A screenwriter has to be much more a filmmaker than a novelist."25 Certainly, the writers of Hiroshima, mon amour and $\underline{L}^{\prime}$ Année dernière à Marienbad, Marguerite Duras and Alain Robbe-Grillet, fit this description.

According to Alain Robbe-Grillet in the introduction to his script for L'Année dernière à Marienbad: "La collaboration entre un metteur en scène de cinéma et son scénariste peut prendre des formes trés variées"(7). But among directors, Resnais is a rare case, because he considers the text equally as important as image and sound. He does not subjugate one aspect for the sake of another.

24 Jean-Claude Carrière, The secret Language of

Films, trans. Jeremy Leggatt (New York: Pantheon, 1994) 147 .

25 Carrière 151. 
"Resnais refuse la primauté totale des images." ${ }^{26}$ In an interview for "Cinémonde" in March of 1961, Resnais said of his work: "Je tenais à composer une espèce de poème où les images ne servaient que de contrepoint au texte." 27 Thus the quality of the text has always been of primary importance for his films, with the result that he has only associated himself with writers of unusual ability. In the case where the script for a particular film was weak, the film itself was also weak. Thus for Resnais, the quality of the text determines the quality of the film.

On the subject of writers, Resnais spoke to "Cinéma $64 "$ in an interview in the December 1960 issue: "Personellement, interièurement je ne sens pas que je choisis des écrivains, je sens que je choisis des gens qui racontent des histoires et qui ont plus de talent que moi pour le faire." ${ }^{28}$ Thus the screenwriter leaves an invisible, but palpable mark on a film. In the words of

26 René Prédal, Alain Resnais (Paris: Minard, 1968) 35 .

${ }^{27}$ Prédal 29.

${ }^{28}$ Prédal $14:$ 
Carrière: "The screenwriter exists only to transmit certain feelings from one person to another. He is today's storyteller, pursuing an ancient tradition with modern means." 29 Resnais takes these 'stories' and gives them another dimension - fleshes them out.

Alain Robbe-Grillet, on the subject of 'nouveaux romanciers' who turned to filmmaking, argues that it is not the objective reality of film that interests these writers, but rather filmmaking as a form of personal exploration, and also the possibilities that sound introduces, because film, unlike literature, possesses a soundtrack. Ultimately for Robbe-Grillet, it is sound that makes film attractive as a medium: "the sound of voices, noises, atmospheres, music and above all the possibility of acting on two senses at once, the eye and the ear..." ${ }^{30}$

Robbe-Grillet's commitment to the modernist ideals of non-linear narrative, unexplained events, lack of conclusion and lack of moral judgment is evidenced in his

${ }^{29}$ Carrière 186.

${ }^{30}$ Alain Robbe-Griliet, For a New Novel trans. Richard Howard (Evanston: Northwestern UP, 1989) 149. 
introduction to the script of L'Année dernière à Marienbad, where he gives us a painfully detailed renditon of a linear film plot and follows it with the filmic possibilities he believes really interest the viewer.

On connaît ces intrigues linéaires du cinéma dit "de papa", où l'on ne nous fait grâce d'aucun maillon dans la succession des événements trop attendus: le téléphone sonne, I'homme le décroche, on voit alors I'interlocuteur qui appelle au bout du fil, l'homme répond qu'il arrive, il raccroche, franchit la porte, descend l'escalier, monte dans sa voiture. File le long des rues, arrête sa voiture devant une porte, monte un escalier, appuie sur un sonnette, un domestique vient lui ouvrir, etc. Notre esprit en réalité, va plus vite - ou plus lentement, d'autres fois. Sa démarche est plus variée, plus riche et moins rasssurante: il saute des passages, il enregistre avec précision des éléments "sans 
importance", il se répète, il revient en arrière. Et ce temps mental est bien celui qui nous intéresse, avec ses étrangetés, ses trous, ses obsessions, ses régions obscures, puisqu'il est celui de nos passions, de notre vie. ${ }^{31}$ Robbe-Grillet's puts his theories to the test in L'Année dernière à Marienbad.

In the opening instructions of the script for L'Année dernière à Marienbad, Robbe-Grillet's initial concern is with sound, with music in particular. He specifies that the film open with the sort of music typically used to end films, and with this he sets up the circular, non-linear structure of the narrative. He also gives great attention to the narrative voice, suggesting that "la musique s'est transformée peu à peu en voix d'homme, lente, chaude, assez forte, mais avec en mêrne temps une certaine neutralité..." 32 The text is built of fragments, repetition and the disjunction of word and image. In reference to one

31 Alain Robbe-Grillet, I'Année dernière à Marienbad (Paris: Les Editions de Minuit, 1961) 10.

32 Robbe-Grillet, L'Annêe dernière à Marienbad 24. 
aspect of this discontinuity Robbe-Grillet suggests: "Les images qui accompagnent ce texte ne présentent pas d'analogie absolue avec les éléments de décor auxquels il I fait allusion." ${ }^{33}$ One such visual schism is described on page 131: "Au-dessus de la cheminée, à la place du miroir, il y a un tableau ancien représentant un paysage enneigé." So the mirror seen in an earlier scene is replaced by the painting of a snow scene. These changes reflect the instability of the characters' memories and at the same time create a rupture in viewer expectations. This same lack of continuity holds true for the juxtaposition of text with the action occurring on screen. The viewer overhears snatches of a conversation between hotel guests which mention "une chaussure au talon brisé,"34 but it is not until later that we actually see that image and when we do, the narrator is discussing something else. The scrambling of text and image destroys continuity and the viewer finds himself on shaky ground in his efforts to determine

\footnotetext{
33 Robbe-Grillet, L'Année dernière à Marienbad 27.

${ }^{34}$ Robbe-Grillet, L'Année dernière à Marienbad 42.
} 
present, past and imaginary episodes.

The repetition of words is seen in the narrator's opening line: "Une fois de plus - , 35 je m'avance, une fois de plus..." and in the description: "à travers ces salons, ces galleries, dans cette construction - d'un autre siècle, cet hôtel immense, luxueux, baroque, - lugubre, où des couloirs interminables succèdent aux couloirs," ${ }^{37}$ which is repeated twice during this opening scene. There are constant repetitions both visually and orally in the references to the hotel, the garden, in the images of games, statues, the shooting gallery, and in the references to the bedroom, which seems to be in a state of constant flux. There is also repetition in the fragments of anecdotes, the fragments of conversation between guests, overheard by the viewer: "Homme: Je ne peux plus supporter ce silence, ces murs, ces chuchotements où vous

\footnotetext{
35 Robbe-Grillet, L'Année dernière à Marienbad 1 .

36 Robbe-Grillet, L'Année dernière à Marienbad 24.

37 Robbe-Grillet, I'Année dernière à Marienbad
} 24,26 . 
m'enfermez..."38 Variations of this speech are repeated several times over several pages. The same disconnected images are restructured within the text and the same fragments of stories are told by different characters using different contexts: a play, an event last year, something that happened to someone else but not here. Repetition of V text and discordance of images is common to the texts of both Hiroshima mon amour and L'Année dernière à Marienbad, but there are also striking differences.

There was an important initial difference in the screenplays by Duras and Robbe-Grillet, which was that /Robbe-Grillet approached Resnais with a completed screenplay or ciné-roman, and Resnais approached Duras with his idea.

Déjà, Resnais... avait demandé à Duras pour Hiroshima d'écrire 'comme Debussy avec le Pelleas et Melisande de Maeterlinck.' Il voulait 'faire opéra,' 'les deux poles du récit, Hiroshima et Nevers, allaient s'entrecroiser

38 Robbe-Grillet, L'Année dernière à Marienbad 36. 
comme des motifs lyriques que Resnais, monteurne, orchestrait dans sa tête." (Robert Benayoun, Alain Resnais, arpenteur de l'imaginaire) un film-opera, une cantate filmée. ${ }^{39}$

Resnais asked Duras to compose a text, with a dialogue, more musical than literary. To write this script, she put aside her usual style in order to write a text that was lyrical, poetic, but with its roots firmly entrenched in the real.

A script differs from a novel in that it is composed solely of dialogue and description. Nonetheless the modernity of Duras's work is evident at the outset of Hiroshima mon amour, when the reader is confronted with the fragment of an image; "Ces deux épaules s'étreignent et elles sont comme trempées de cendres, de pluie de rosée ou de sueur, comme on veut."40 The dialogue of the two lovers concerns not the crooning words of love, but incongruously

39 Jean-Michel Frodon, L'age moderne du cinéma français (France: Flammarion, 1995) 73.

40 Marguerite Duras, Hiroshima mon amour (France: Gallimard, 1960) 21. 
they speak of the aftermath of the atomic bomb dropped on Hiroshima. Then without warning the scene shifts from the bodies of the lovers to an almost impersonal tour of f Hiroshima, and the voices superimposed over the images become almost like a documentary travelogue. In the opening scene of part two of the script there is a description of the young French woman, looking at the hands of the sleeping Japanese man and then there is a shift:

Tandis qu'elle regarde ses mains, il apparâ̂t brutalement à la place du Japonaise, le corps d'un jeune homme, dans la même pose, mais mortuaire, sur le quai d'un fleuve, en plein soleil. ${ }^{41}$

/We are given no explanation for this shift. Throughout the text, the shifts are made from one scene to the next without warning, without any kind of linking, and at the end of the text, one is still uncertain of the outcome. Repetition is seen in such phrases as "Tue me tues. Tu me

41 Duras, Hiroshima mon amour 43. 
fait du bien," ${ }^{42}$ in her lover's pleas for her to stay and in her refusal, as well as the constant use of the two names Nevers and Hiroshima. This repetition creates the rhythm of the text, which like L'Année dernière à Marienbad / can be classified as a modern work.

Analysis of Marguerite Duras's writing shows how her works fit the definition of a modern text. In Subversive Intent: Gender, Politics and the Avant-Garde, author Susan Rubin Suleiman says of Duras's works: "They privilege the fragment, the gap, the incompletion, postponement, they are written in a language that perturbs..."43 Hiroshima mon amour is rife with these gaps and fragments, this incompletion and postponement, in short this non-linear development. The already mentioned scene where the image of the sleeping Japanese lover is replaced by that of the dying German soldier illustrates this sutured development very well. Suleiman further suggests that Duras's writing

42 Duras, Hiroshima mon amour 35.

43 Susan Rubin Suleiman, Subversive Intent: Gender, Politics and the Avant-Garde (Cambridge: Harvard UP, 1990) 100 . 
demonstrates its modernity "by its repetitive, almost hallucinatory quality and its love of silences..."44 The following are two more examples of how Duras employs language to achieve the rhythmical sort of repetition seen in Hiroshima, mon amour:

ELLE

Je suis d'une moralité douteuse, tu sais

LUI

Qu'est-ce que tu appelles être une moralité douteuse?

\section{ELLE}

Douter de la morale des autres. ${ }^{45}$

\section{ELLE}

C'est à Nevers que j'ai été le plus jeune de toute ma vie...

$$
\text { LUI }
$$

Jeune-à-Ne-vers .

ELLE

Oui. Jeune à Nevers. Et puis aussi, une fois, folle à Nevers. ${ }^{46}$

These two examples were chosen from many; there is not a

44 Suleiman 100.

45 Duras, Hiroshima mon amour 55.

46 Duras, Hiroshima mon amour 57. 
page of dialogue that is not equally endowed with the same sort of rich measured prose. Suleiman concludes that Duras's texts "contest and subvert traditional narrative authority and coherence." ${ }^{47}$ Hiroshima, mon amour not only employs a non-traditional narrative style, but there is also a non-traditional aspect to its presentation of history.

Although not an element of modernism, historical context plays a crucial role in Resnais's thinking and in the majority of his films, and it seems that at least in Hiroshima, mon amour Duras shares his point of view on the place of history in the film. In terms of historical content, Hiroshima mon amour speaks of the shift from the private domain, private history, to the realm where public and private history merge.

Hiroshima mon amour is the first Durassian work where public (social, external, political) history appears in the Foreground; up to that point the novels and stories are explored

${ }^{47}$ Suleiman 100. 
private (personal, internal psychoanalytic) history. ${ }^{48}$

Instead of the 'romance' having a war-time background, the history of the war predominates, with the thread of two romances running through it.

Thus far Hiroshima, mon amour has been discussed as a modern novel and in terms of its history, and we will now consider this work in terms of Duras's working relationship with Resnais. In the preface of Hiroshima, mon amour, Duras writes: "Mon rôle se borne à rendre compte des éléments à partir desquels Resnais a fait son film."49 She continues: "Je livre ce travail à l'édition dans la désolation de ne pouvoir le compléter par le compte rendu des conversations presque quotidiennes que nous avions, A. Resnais et moi..."50 Resnais may modestly hide behind his co-authorial relationships, but self-effacing or not it is well-known

48 Nancy Lane, "The Subject in/of History," Literature and Film in the Historical Dimension, ed. John D.Simmons (Gainesville: U of Florida, 1994) 90.

49 Duras, Hiroshima mon amour 57.

50 Duras, Hiroshima mon amour 57. 
that "he has altered every script he has ever filmed." ${ }^{1}$ In the case of Hiroshima mon amour, it can certainly be said that ultimately, "the film itself is as much a product of Resnais's vision as of Duras's scenario."52 For Resnais a script and its narrative are merely the starting point, and that can be said as well for the viewers of his films.

For the viewer, the narrative is perhaps the most easily recognizable part of the film. Like the melody of a piece of music, but hidden behind this melody, at counterpoint to it, and weaving throughout it are all the director's other concerrs, interests and motivations. The script itself is the raw material, but "every Resnais film transcends its script..."53 A poignant example of this is / seen early in Hiroshima, mon amour during the documentary footage of the aftermath of the bomb when Resnais juxtaposes images of mutilated children with the voice-over of the French woman telling of flowers blooming.
51 Kreidel 17.
52 Lane 89.
53 Kreidel 17. 


\section{ELLE}

...du quinzième jour aussi.

Hiroshima se recouvrit de fleurs. $\mathrm{Ce}$ n'étaient partout que bleuets et glaieuls, et volubilis et belles-d'un-jour qui renaissaient des cendres avec une extraordinaire vigueur, inconnue jusque-là chez les fleurs. ${ }^{54}$

The emotional depth achieved by Duras in Hiroshima mon \# amour differs strikingly with the cool superficiality of Robbe-Grillet's L'Année dernière à Marienbad.

Like the work of Duras, the novels of Alain RobbeGrillet fit the criteria of modernism, in that they are:

$$
\text { ... nonreadable in terms of traditional }
$$

criteria of linearity, coherence, noncontradiction and psychological depth of characters. It does not mean however...that his fiction has no order of its own. On the contrary, he maintains that his works are highly complex and ordered systems; it is all a

${ }^{54}$ Duras, Hiroshima mon amour 28. 
question of the kind of order one is looking for. ${ }^{55}$

But the history of the script for L'Année dernière à Marienbad is nothing like the writing of Hiroshima mon amour. Robbe-Grillet, an expert at self-promotion, has written extensively, specifically on his novels and films as well as on literary and film theory. Resnais is much more reluctant than Robbe-Grillet to express his point of view, preferring to let the viewer come to his own conclusions. Thus there exists considerably more material on Marienbad from Robbe-Grillet's perspective than from Resnais's, which has resulted in the script-writer's version being the accepted point of view on the film.

In his book, Screening the Text, T. Jefferson Kline disputes the 'word' according Alain Robbe-Grillet. He suggests that Resnais was unfamiliar with Robbe-Grillet's work prior to their coliaboration, that their collaboration was one long misunderstanding, and that when Resnais realized his error, he was already too committed to the 
project to back out. Kline presents persuasive evidence that Resnais was able to make Marienbad despite RobbeGrillet, rather than because of him, and his research sheds light on many of the inconsistencies surrounding the film. First of all, Kline argues that Resnais does not like to work from a finished book: "If the book already exists, $\checkmark$ it no longer seems interesting ('ça ne m'amuse plus)."56 Resnais has also been quoted as saying "Personally, I don't like adapting films from books,"57 and that for the same reason he has little interest in working with finished scripts. He sees it as dead matter ("une matière morte.")58 Second, Kline notes that Resnais asks his writers not to think about film technique- "ne pas penser à la technique cinématographique" 59 -but to concentrate on their own medium. And so what does Robbe-Grillet proceed to do,

56 Jefferson T. KIine, "Rebecca's Bad Dream:

Speculations on/in Resnais's Marienbad," Screening the Text: Intertextuality in New Wave French Cinema

(Baltimore: The Johns Hopkins UP, 1992) 66.
57 Kline 66.
58 Kline 66.
59 Kline 66. 
but to write the project entirely on his own and to present Resnais with a 'fait accompli.' Robbe-Grillet not only \# frote the text, but included instructions for lighting, music and camera placement, complete to the last detail. Resnais found himself imprisoned by the script. He later said to "I'Arc" of their arrangement that he had had the impression "de faire office de robot-électronique dans la confection du film."60 In another interview on Marienbad, he is quoted as saying: "Nous étions tous obligés de suivre un chemin dont nous ne pouvions pas nous échapper... Nous $\sqrt{ }$ étions en quelque sorte prisonniers... pas libres." ${ }^{11}$ So if Robbe-Grillet speaks of the text as a 'persuasion', a seduction, it also seems possible that Resnais found + himself in the position of being a victim of persuasion. How deep their differences went can be seen in this line from their joint interview for Cahiers du Cinéma: "Nous n'avons pas du tout les mêmes gouts et il arrive que nous nous opposons violemment, sur un livre, sur un film, sur
60 Kline 67.
61 Kline 67. 
un mode de vie."62 The emphasis is Resnais's. The implication is that Resnais uses non-text, non-literary techniques to subvert Robbe-Grillet's intentions.

Marienbad differs from Resnais's other films in several major respects. First, his films often use women as the main protagonists, and even in those films where that is not the case, such as in Providence, the male characters explore the more feminine side of their natures. Resnais's films as a whole have a decidedly sensitive, feminine aspect. He often employs psychological 2 perspectives in his films and his characters definitely exist in a framework that includes a past as well as a present. Second, Resnais abhors violence, and his films

3 demonstrate the unacceptability of violence as in Nuit et Brouillard, Hiroshima, mon amour and Murial. The exception to this point of view is L'Année dernière à Marienbad, which has a major male protagonist and is at the same time agressively masculine in tone and filled with supressed Violence. The film seems to largely reflect the author 62 Kline 69. 
rather than the director. Robbe-Grillet is a one-trick pony who has built his entire reputation on violence against women, both in his books and on the screen. Kline refers to his films as "sadomasochistic reveries."63 Susan Suleiman, speaking of Robbe-Grillet's projet pour une révolution à New York, summarizes his thematic material as "sexual agression... practiced by men on the bodies of women."64 His point of view would have been entirely unacceptable to Resnais, but the director was stuck with the script and with its writer.

Kline further suggests that the ongoing struggle of Resnais against Robbe-Grillet mimics the scenario itself, that the male protagonist is Robbe-Grillet and his victim is Resnais, and further, that Resnais did the only thing possible against the double tyranny of writer and script; he quietly revolted. This can be seen in a number of ways: $\mathcal{V}$ in the bombastic organ music which drowns out the narrator (Robbe-Grillet) at the beginning of the film, in his

\footnotetext{
63 Kline 69.

64 Suleiman 54.
} 
refusal to portray the violent and explicit rape scene called for in the text, and the inclusion of a poster for Ibsen's Rosmersholm ${ }^{65}$ twice within the film, which gives the film a depth, a literary background and reference unintended by Robbe-Griliet, and thus robs the film of its $\sqrt{ }$ intended superficiality and skin-deep sexuality. Resnais never thought of the characters as mannequins, the robotic one-dimensional creatures of Robbe-Grillet's imagination. On the contrary, as he explains, Resnais always considered them as real, with a past and future:

For me the characters are real beings. They have their own lament and mysterious life... Marienbad describes the hesitations, the madness, the anguish and the moments of great happiness that accompany any passion... Realism doesn't exclude ambiguity, on the contrary... One wonders if it isn't a dream, imagines the best and the worst. I was working entirely within psychological realism! of course, when I

${ }^{65}$ This play deals with seduction and documents the rise and fall of a woman's political and sexual powers. 
say 'psychology' I'm not limiting myself to conscious or present behavior. There are images that inspire or prevent action.... Others derive from phantasy and the unconscious. A more or less stereotyped unconscious. Marienbad is composed of just such images... The unconscious is also a spectacle, perhaps the fundamental spectacle. ${ }^{66}$

The basic difference in sensibility and in motivation between Robbe-Grillet and Resnais underlies the differences

$\checkmark$ between L'Année dernière à Marienbad and Hiroshima mon amour, though the two films share stylistic features. These differences include such polar opposites as masculine and feminine, violence and ron-violence, and un style figé versus one that is open and evolves. The rapport Resnais shared with Duras and the film that resulted from their collaboration are much more typical, both in terms of his working style and the nature of the finished film.

The collaboration between Resnais and Duras fits

${ }^{66}$ Kline 74. 
Carrière's definition of a 'good' screenplay but this cannot be said of Robbe-Grillet's Marienbad. According to Carrière a good screenplay is:

one that gives birth to a good film. Once the film exists, the screenplay is no more. It is probably the least visible component of the finished work. It is the first incarnation of a film and appears to be a self-contained whole. But it is fated to undergo metamorphosis, to disappear, to melt into another form, the final form. ${ }^{67}$

But to Resnais, the screen play is much more than this. It is also a part of his own initial creative process, intended to be a joint venture with a writer he respects, the opportunity to create a living structure for the film, something that contains within it numerous possibilities, both for filming the piece and for viewing it.

On the film's text, Carrière further suggests that in a cinema dominated by screenwriters, content would outweigh

${ }^{67}$ Carrière 148. 
form, with the result that "the film would be made only to illustrate the screenplay, not the screenplay to allow the film to come to life."68 And this is exactly the problem with Robbe-Grillet's script for L'Année dernièe à Marienbad. If the screenplay dominates the film not only is there "a weakening of the image in favor of words," ${ }^{69}$ but there is also a weakening of the creative influence of the director and of the role of the viewer, both of which are $\checkmark$ essential to Resnais's work.

Thus we see how Robbe-Grillet's text, although indicating specific film techniques, does not permit the director to be an auteur but merely a metteur en scène, while Duras's screenplay is open enough to allow Resnais full use of the creative potential of the text.

${ }^{68}$ Carrière 43.

69 Carrière 43. 
CHAPTER IV - THEMES, PLOTS AND INTENTIONS

In film, plot and theme make up the visible, tangible structure which manifests the director's intentions. This is easily seen in Resnais's work, where the themes and plots directly represent the director's point of view and his concerns, while his intention to encourage viewer responsibility lies below the surface. The themes which he explores again and again are the many aspects of love and grief, memory, the psychological link of sex with death, and the psychology of obsession. Resnais uses these themes $\checkmark$ in his efforts to increase viewer awareness and individual responsibility.

As a background for discussion of Hiroshima mon amour and L'Année dernière à Marienbad. I will first give a brief synopsis of the films. The opening of Hiroshima is ambiguous; the closely cropped bodies of entwined lovers are inter-cut with documentary footage of the aftermath of the bombing of Hiroshima and the city as it stands today. It is unknown if the bodies are male or female, if they are covered with dew, sweat or atomic ash. Following the 
opening scenes, the camera returns to the hotel room for a series of scenes in bed, outside on the balcony, in the shower, characters dressed and undressed. Next there is a morning departure scene, and a rapid cut to the afternoon and a parade, which is part of the final day of shooting a film on peace. That sequence is followed by a rapid cut to the home of the Japanese lover. There are two scenes there and we are next shifted to a bar, but the general close cropping of the scene at the bar does not permit the viewer much detail of the surroundings. Then the story of the actress's youth in Nevers, France and of her war-time romance with a German soldier is inter-cut in flashbacks during a conversation in the bar. The bar closes and the woman returns to her hotel, there is a short scene there, and she then returns to the nightlife of the city. Her lover follows her through the streets, into a bus or train station, and then into a bar. The final scene returns to the hotel.

L'Année dernière à Marienbad is the story of a seduction, one that has perhaps happened before, that is also happening in the present, perhaps for the second time, 
and which is discussed and alluded to constantly throughout the film. There are three main characters, a woman ' $A$,' her seducer ' $\mathrm{X}$ ' and the woman's husband or protector ' $M$. '

The main action of Marienbad takes place in three distinct areas, the public areas of a hotel, the hotel garden and one specific guest room. These three locations are constantly inter-cut. The content of the text which is repeated during the opening monologue makes references to the story having taken place before. This monologue, which introduces the film, foreshadows all the action of the piece, as does the entire text. This foreshadowing includes the film as a whole as will as all the small events that make up its individual scenes and sequences. From the opening scene of the film we are taken to the final. scene of a play, which textually will also be the final scene of the film, where the narrating voice of the introduction blends to become that of the actor on stage.

In Marienbad, after the opening, we cut abruptly from the play to the lobby, where we hear snatches of conversation between a coiple whose personal history, told with many references to the garden, is also a synopsis of 
the film. The film is made up of rapid and constant displacements of one image with another, one location with another, and most of these are deep-focus shots and stationary. After the lobby, there are more interior hotel shots: empty room and hall shots, the shooting gallery and a darkened cellar, a bar, dancing in the ballroom, salons, stairs and the gaming room. There is actually very little Sdialogue in any of these scenes. Voice-over replaces $f$ dialogue in most of the film. From the interior of the hotel we are then taken for the first time to the statues in the garden. We see the story of the broken heel while Jthe off-screen voice tells another anecdote. We see more interior shots and return to the garden once again. More dancing follows and we are introduced to the hotel bedroom in the first of its many incarnations. The film then cuts back to the bar and returns to the bedroom which gains and loses furniture and other objects each time it is seen. The scene shifts rapidly between the bar and ballroom and the bedroom with occasional forays into the garden. The viewer then proceeds to a concert which is also interspersed with images of garden and bedroom. The number of bedroom shots 
and the pace increase, linked with a return to rapid, rather frenzied shots of the corridors. Finally there is a series of climaxes or resolutions to this pent-up burst of energy and the film ends with the female protagonist waiting at the foot of the stairs to leave with her seducer. Thus the whole film is a series of actions and events, but whether in the present or the past is uncertain, and inter-cut within these events and actions which are taking place on screen are other actions and events which are seen or heard or both, some directly through lines characters speak and images that are seen, some alluded to or described in visual detail by the narrating voice. ${ }^{70}$ Even from these brief synopses, Resnais's main themes are evident.

Desire, fear and hate, and mourning are the emotional

70 In The Films of Robbe-Grillet author Roy Armes offers a different and even more precise breakdown of the film. He groups the film into shots, the shots into scenes and the scenes into sequences, giving the text with which each group of shots begins as well as the number of shots in each scene and including the number of feet of filmstock used.

Roy Armes, The films of Alain Robbe-Grillet (Philadelphia: John Benjamins North America, 1981) 
underpinnings in Hiroshima mon amour and $\mathrm{L}^{\prime}$ Année dernière à Marienbad. Desire as a manifestation of love is the first and most obvious of these. In Hiroshima it is first of all the love or desire that exists between the French actress lesire and the Japanese architect and secondly the love or desire that existed in the past between the same woman and a young German soldier. It is desire that has charted the course of her entire life. In Marienbad it is the desire of the man ' $X$ ' for the woman ' $A$ ' which creates the action of the film. It is desire which creates both the conflict and whatever resolution the film permits.

The second emotion underlying Hiroshima mon amour is grief or mourning. The French actress has been in a state of permanent mourning since the death of her German lover over fifteen years ago. This event forms her and her world. In Hiroshima, desire and grieving go hand in hand. The set of negative emotions presented in L'Année dernière à Marienbad are fear and hate. The man ' $\mathrm{X}$ ' mixes an underlying current of hate with his desire for the woman 'A.' In her we see no desire at all, only the fear of ' $\mathrm{X}$,' of loss, death and the unknown quantjty of change. For ' $\mathrm{X}$, ' 
the woman's fear is an integral part of the love relationship. In both films, all of the emotional content has its origins in the past, and the present is nothing more than an inevitable product of this emotional history.

In Resnais's work the central theme is often the $\eta_{\text {interrelations of repetition, remembering and love and how }}$ amour the female protagonist equates sex with death, as the result of her spiritual death after her first lover, the German soldier, is killed. In L'Année dernière à Marienbad the female protagonist also equates sex with death. If she leaves with the man who desires her, she fears the result will be rape or death. This fear is manifested in the shooting scene. In these two films, the relationship between desire and death, or sex and death, is a major psychological link in the narratives.

The second psychological factor is obsession as manifested in repetition. Sigmund Freud identifies the compulsion to repeat as a means of mastering difficult material, as an obstruction and an aid in psychotherapy, 
and as a key to the death instinct. ${ }^{71}$ In the practice of psychotherapy, repetition is encountered as a hindrance to memory or, more properly, as a means of remembering that can be exploited in a transference situation. For example, a patient acts out a past trauma in the present, without being aware that he is repeating earlier events and behavior. The patient repeats because his repressions keep him from remembering the traumatic material, and because nevertheless the material is trying to express itself. "When the motivating energy of this urge to repeat originates in the unconscious, that impulse is called the 'repetition compulsion." 72 This compulsion is also a means to relieve tension. "On a psychotherapeutic level, this compulsion acts in the service of the most immediate and inaccessible form of memory, forcing us not to remember but to relive unmastered material."73 The individual may find

${ }^{71}$ Bruce F. Kawin, Telling it Again and Again: Repetition in Literature and Film (Ithica: Cornell UP, 1972) 16-17.

\footnotetext{
${ }^{72}$ Kawin 17.

73 Kawin 17.
} 
himself repeating, rather than remembering traumatic experiences. In Hiroshima mon amour the female protagonist $\checkmark$ finds herself unknowingly recreating the forbidden love of her youth, this time with a Japanese lover. The viewer also sees transference take place with the woman and her lovex in the bar scene when she recalls the past trauma. Transference is the assigning of the identity of an individual from a past trauma to someone in the present, and reliving or working out the trauma using the substitute. In $\underline{L}^{\prime A n n e ́ e ~ d e r n i e ̀ r e ~ a ̀ ~ M a r i e n b a d ~ t h e ~ e n t i r e ~ f i l m ~}$ could be categorized as 'repetition compulsion,' with the difference being that the narrator, the protagonist ' $\mathrm{X}$,' is aware of the repetition but is unable or unwilling to end it. As for the forgotten trauma, it could be a rejection, a rape or a shooting. ' $X$ ' refers constantly to all that he believes has gone on before and sees as recurring. These two psychological aspects which Resnais links with love and mourning are also tied to his concepts of memory.

In Resnais's films the dual concepts of remembering and forgetting, as well as of past and present, function in terms of memory and time. Global and personal history 
function within the constructs of memory and time. In Hiroshima, mon amour,

the suffering and death caused by the atomic bomb and the young girl's own suffering and ritual death (she is entombed in the cellar) become metaphors for each other as parallels between present and past, public and private multiply at all levels. ${ }^{74}$

Resnais uses his films to explore memory, remembering and forgetting as an unreliable means of distinguishing between truth and lie. In both Hiroshima mon amour and L'Année nory

dernière à Marienbad the characters evidence the inability to distinguish the truth. This is shown in the opening scenes in Hiroshima when the female protagonist describes the aftermath of the atomic bomb in completely implausible and impossible ways. Her description reflects our own inability to remember history accurately whether public or private. We also hear her lover questioning her honesty and her admitting that she lies. In Marienbad ' $X$ ' keeps 
altering the story like a clever con artist or fake fortune teller who tries out versions of a story until the listener approves or validates it. We also hear ' $A$ ' lie to her protector ' $M$ ' about a photo, and we watch her increasing inability to distinguish reality from fantasy, truth from lie. And by the end even ' $X$ ' has difficulty keeping his stories straight. Even though direct ethical judgements are missing in these films, and there are no adverse consequences for the protagonists who lie, there is an implied judgment on war, on violence, and on the bombing of Hiroshima. How the characters in the films remember and forget events forces us, the viewers, to reflect upon our abilities, upon how we view and remember events and / history, both public and private.

Resnais links public conscience with history and politics. He does not believe the viewer can escape these obligations. Resnais's recurring themes include history, the past and its effects on the present, the frailty of memory, the inability to remember or forgetfulness, the role of love and desire, the meeting of the imaginary and the real. In his choice of themes we are forced to examine 
the idea of conscience to such a degree that conscience itself, like time, love and memory, becomes a central theme / of his films. French scriptwriter Jean-Claude Carrière says of film: "It remakes history, it helps recount the past, it becomes history itself"(144). Resnais looks at truth and lie as an aspect of political relationships as well as personal ones. Even though Resnais makes no specific judgment, he looks at the judgments of others. Specifically, in Hiroshima mon amour, he looks at the Church's judgments against fornication and adultery and murder, and how the Church allows itself to be used as a political tool when expedient. This is seen in the French $\checkmark$ woman's memory of the church bells ringing at the end of the war, and during her incarceration in the cellar. Resnais also looks at scciety and social conduct, what can and cannot happen or be said in public, and how society views and deals with transgressors. Again this code of behavior can be altered when politically expedient. This code of behavior includes public facades, that is to say manners, prohibitions against public insanity and prescribed notions of the nature of sanity. The sanctions 
against war, killing, rape and adultery are mutable.

For Resnais confronting history becomes a matter of individual responsibility. Resnais's films confront history, both public and private. He makes us look at what we consider to be true and reevaluate it. He leaves the matter open, presents the material and leaves it to us, the viewers, to judge. At the same time he shows us the impossibility of judging well because of our inability to sustain memory, remembering imperfectly or inaccurately or not at all. Heinrich Boll wrote: "Reality demands our $\checkmark$ active, not passive attention."75 Resnais makes seeing and judging an aspect of the viewer's responsibility. Carrière suggests that:

... we keep our eyes open in the dark or we think we do. But do we not harbor deep within us some taboo or habit or faculty or obsession that blinds us to all or to part of the audiovisual band that flickers fleetingly before us? ${ }^{76}$

75 Carrière 146 .

76 Carrière $4-5$. 
As we blind ourselves to what is happening on screen so we censor our memories and refuse to see our lives or history for what it really is. Our responses to Resnais's films are a compressed extension of our responses to daily life. Carrière continues: "We believe we are looking, but we delude ourselves. Without knowing it... having too much to see, our eyes no longer see at all."77 This belief in the mutability of human memory and in the existence of viewer 'blind spots' is central to Resnais's work.

How many times could we say, of ourselves or of others, that a film has not been seen, or truly seen? For many reasons, some of which are unclear and some we cannot admit to, we see imperfectly. We refuse to see, or else we see something else. There is in every film a region of shadow, a stockpile of the not-seen. It can be put there by its authors, knowingly and deliberately. And it can be brought there during the performance by a particular spectator (just one spectator who on

77 Carrière 17-18. 
that one day is unable or refuses to see everything), or else by that remarkably cohesive group whose reactions are collective even when unpredictable, the entity known as the audience. ${ }^{78}$

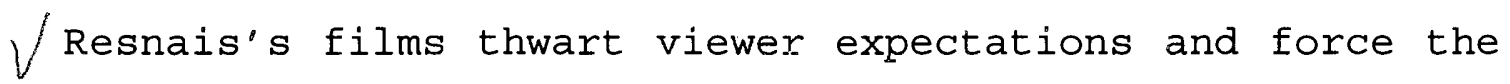
viewer to reevaluate his thinking.

For Resnais, aiding the viewer in learning to see, to discriminate, is a personal obligation and an aesthetic necessity. Resnais believed that one could really learn how to look at things, and that the viewer must be given the freedom to decide for himself rather than be led along a series of immutable paths to a pre-determined conclusion. In this vein, critic James Agee says of film: "But there is only one rule for movies that I finally care about: that the film interest the eyes, and does its job through the eyes."79 In other words, does its teaching visually. And for Resnais the specific 'job' or responsibility of both filmmmaker and viewer is learning to see. Agee also spoke

78 Carrière 4-5.

79 James Agee, Agee on FiIm (New York: McDowell, Obolensky, 1958) 305 . 
of John Houston's films, but the quote works equally well for Resnais:

His pictures are not acts of seduction or of benign enslavement but liberation, and they require of anyone who enjoys them, the responsibilities of liberty. They continually open the eye and require it to work vigorously; and through the eye they awaken curiosity and intelligence... It is unquestionably essential to good art. ${ }^{80}$

$\mathcal{L}$ Resnais also employs plot as a means to increase viewer awareness.

The plot is the means by which the director structures events in time. In both Hiroshima mon amour and L'Année dernière à Marienbad there is a shift in time when the past becomes the present. In Hiroshima this shift occurs when the French actress sees, in place of her Japanese lover, a long-dead, German soldier and also in the bar scene, when she relives her youth in occupied France. In Marienbad, 
this shift becomes more and more extensive, and more pervasive as both the characters and the viewer become $\sqrt{ }$ uncertain as to what is occurring in the present or in the past. The scenes that take place in the garden and in the bedroom, and the characters' conversations become progressively more muddied as to context and continuity.

One view of this ordering of events in Hiroshima mon amour is explained in The Erotic Dream Machine:

Hiroshima mon amour: Duras' text added a layered dimension to the images, Hiroshima mon amour resolves divergent worlds and experiences by intersecting at the present moment with the memory of the past. Guided by a distinct chronological order of the events occurring in history, Hiroshima mon amour travels back and forth in time through memory. The Nazi occupation of France and the dropping of the atom bomb on Hiroshima give the film referents outside the characters and help to orient the viewer. ${ }^{81}$

${ }^{81}$ Fragola and Smith 5. 
In Hiroshima the past becomes the present as the woman relives her war-time youth in post-war Hiroshima. In Marienbad the past intrudes upon the present, as a real or imagined past love affair collides with a present-day seduction, to the point where the two become one and the same.

Resnais uses time in his films as a function of remembering and forgetting. Both plots are built around the $\checkmark$ heroine's inability or unwillingness to remember. In Marienbad, in the second exchange between the woman ' $A$ ' and the man ' $\mathrm{X}$,' the theme of remembering and forgetting is introduced:

A: "Pourquoi me regardez ainsi?

$\mathrm{X}$ : "Vous ne semblez guère vous souvenir de moi." 82

In Hiroshima, the idea of forgetfulness is also introduced early in the film, at the moment of the lovers' departure, the morning after their first night together:

ELLE

Nevers, tu vois," c'est la ville du monde, et même

82 Robbe-Grillet, L'Année dernière à Marienbad 52. 
c'est la chose du monde à laquelle, la nuit, je rêve le plus. En même temps que c'est la chose à laquelle je pense le moins. ${ }^{83}$

$/$ In Resnais's films, time is the most overt element of plot. A second element of plot is the juxtaposition of desire and the fear of desire. It is the desire of the two characters in Hiroshima and the desire of ' $X$ ' in Marienbad that move the action along. The fear of the two women in response to this desire also serves as counterpoint to move the plot forward. This fear is a palpable part of the text in Marienbad. For example, in Robbe-Grillet's directions for one close-up of 'A,' he says: "A faisant "non" de la tête. Visage sérieux, imperceptiblement effrayé."84 The repetition of these elements in both text and image is evident in both films. In Hiroshima, the French actress is pursued by her Japanese lover, and she keeps refusing to meet him again or to stay longer in Hiroshima. In Marienbad, the woman ' $A$ ' repeatedly denies any previous

83 Duras, Hiroshima mon amour 58.

84 Robbe-Grillet, L'Année dernière à Marienbad 73. 
acquaintance with the man ' $\mathrm{X}$ ' and begs him to leave her alone: "A: Laissez-moi... je vous en supplie..." ${ }^{85}$ This repetition of elements, plus a lack of resolution, gives the two plots a circularity of action. In each film, there is a sense of the plot folding in upon itself.

Plot involves action, idea and character. The plot involvement of character is seen as the viewer witnesses the characters' private actions and thoughts. In Marienbad, many of the private actions concern ' $A$ ' alone in her room. In Hiroshima, there is one scene where the actress is alone in her hotel room after telling her lover of her past. This $\sqrt{ }$ is the most revealing scene in the film in terms of character, because we see her stripped of her public persona. As already noted there is a circular aspect to Resnais's plots and action, but this circularity extends also to the relationships between characters, which do not change within the duration of the film. They seem frozen in time, fixed in their compulsion to repeat, to project the past upon the present. In Hiroshima, the catharsis of

${ }^{85}$ Robbe-Grillet, L'Arnée dernière à Marienbad 102. 
remembering and revealing her past makes no fundamental change in the actress. Loving her has not altered the Japanese architect's life or plans. At the end of Marienbad, one surmises that ' $A$ "'s life will be no better or worse with ' $X$ ' than with ' $M$,' that having made the decision, her life will go on much as before. It was merely making the decision, making the change, that ruffled the placid surface of her nature, but only for the moment. Thus we see that Resnais's characters are archetypes who undergo / no real psychological changes during the films.

Ideas are implemented in the plot as Resnais uses the characters to represent various points of view and philosophies. For example, in Hiroshima, the French actress is in Hiroshima to make a film on peace. As an outcome of the war, her Japanese iover wants to enter politics. The two characters do not share the same sentiments on or memories of the day the atomic bomb fell on Hiroshima. Resnais uses these characters to promote his personal feelings on war. In Resnais's plots, character and action serve to provide physical evidence of his varied themes. Of these themes, learning how to see is the idea that 
informs all of Resnais's work. Resnais is not so arrogant as to believe that he can teach the viewer to see. But he realizes that seeing is a cumulative process and he attempts to provide an occasion, an opportunity where learning can occur. And to this end in his films, he sets a series of tasks for the viewer. For instance, in Hiroshima, mon amour, the opening documentary footage forces the viewer to confront his own ignorance, memories and misconceptions of the dropping of the atomic bomb on Hiroshima. The influence of this strategy extends far beyond the viewing time of the film. Memory in general, with its remembering and forgetting, is brought into question, provoking one to doubt one's own memory of other public and private events. This use of non-linear development is one of Resnais's strategies to prod the viewer out of a passive state. One cannot sit, mentally absent, and watch L'année dernière à Marienbad. The organization of the film forces the viewer to attempt to untangle the disjointed narrative.

The areas of conflict which propel the plot and action forward echo the already suggested themes: death and 
desire, remembering and forgetting, truth and lie, imaginary and real, and the struggle of past and present. These areas of conflict can be seen as both internal and $\checkmark$ external struggles. In Hiroshima mon amour, the heroine openly lies, she represses the truth about her past, her desire for her lover, and the effect of the war on her life. Her struggles mimic our own lies in terms of justifying the war, repressing or misrepresenting our part in the dropping of the atomic bomb and minimizing its aftereffects. In $L^{\prime}$ Année dernière à Marienbad, it is the supressed violence beneath the desire, the seduction, the persuasion, the so-called romance that creates the lie. The truth of ' $\mathrm{X}$ "s intention are called into question just as much as is his version of the past. The surface of his intent is as shallow as the beautiful setting in which the action occurs: "A: Vous êtes comme une ombre, - et vous attendez que je m'approche - Oh, laissez-moi... laissezmoi... laissez-moi!"86 Several times in the next few pages of dialogue ' $\mathrm{X}$ ' concludes his speeches with "Vous avez

${ }^{86}$ Robbe-Grillet, L'Année dernière à Marienbad 114. 
peur," and later during his remembrance of the rape scene, that Resnais chose not to shoot, ' $X$ ' elaborates: "Vous avez toujours eu peur. Mais j'aimais votre peur ce soir-là."87 Thus dialogue, voice-over and monologue are used to convey the internal and external conflicts of characters.

As previously stated, Resnais's primary intention is to aid the viewer in learning to see. To my mind this is his only goal in making films. This intention is seen in terms of aesthetics as well as politics, philosophy and ethics. According to this view, his work is neither a vehicle for specific meanings, a contrived act of communication for the purposes of viewer manipulation nor an act of partially self-aware expression. Resnais deliberately and carefully creates a multi-layered completely open-ended work. Except for a pronounced abhorrence of violence and war, Resnais attempts to lead the viewer nowhere and everywhere. It is up to us to pick and choose the bits we want to keep, reject, enhance, invent, ignore, or delete.

87 Robbe-Grillet, L'Annếe dernière à Marienbad 126. 
The sensory data of the film at hand furnish the materials out of which inferential processes of perception and cognition build meanings. Meanings are not found but made. ${ }^{88}$

Resnais's films are highly manipulated, but only towards a freedom of choice for the spectator. "All expression... lives on acknowledged or unacknowledged memories, personal reminiscences..."89 Our own memories and experiences are $\checkmark$ what enable us to endow other experiences with meaning. But Resnais never lets us forget of the ultimate impossibility of relating to others' experiences. As Ingmar Bergman states: "The story you tell isn't the same as the story you hear."90 Resnais's only requirement is that we, the spectators, be active participants in the viewing experience, and that we constantly question the veracity of what we see and hear. As Carrière insists: "Let us never forget that language, of whatever kind is inherently

${ }^{88}$ Bordwell, Making Meaning 2.

${ }^{89}$ Carrière 16 .

90 Carrière 32. 
deceptive."91 Resnais's films remind the viewer of the deceptive nature of language and of image, and that learning to see is an acquired skill and an active process. In the following chapter we will see just how film technique contributes to this process and supports Resnais's intent.

91 Carrière 231. 
CHAPTER V - TECHNOLOGY

Resnais's films, Hiroshima mon amour and L'Année dernière à Marienbad, released respectively in 1959 and 1961, have been exhaustively studied for over thirty-five years, but studied only in terms of traditional literary criticism. As noted earlier in this thesis, film criticism has appropriated the structures of literary criticism and applied them directly to film. I have not found a single instance nor a single analysis that includes film technology as a valid means for comprehending a film. Yet Carrière suggests that "through the ceaseless technical fever that is its hallmark, the cinema... has played an irreplaceable role in the exploration of connections: among images, feelings, characters."92 Image, text and sound are the physical building blocks of film, and film, as a medium, depends upon the sequential and simultaneous ordering of these three elements to achieve communication. What results from this technical organization is dense layered meaning.

92 Carrière 29. 
Unless designated 'made for television,' films are intended, by design, for the big screen. Movie theaters are like places of worship where day to day reality is altered, the mundane physical aspects of life drop away and longneglected senses and emotions are called forth. We are alone in the dark with this intimidatingly large glowing object. Certain of our senses are subdued, others are intensified. Our awareness of our surroundings and of time is diminished. We leave a movie theater as if after a long voyage, surprised to find that it is still day or that it has become night. ${ }^{93}$ On this screen the human form appears god-like in its dimensions, at once intimately connected to us and at the same time elevated beyond us. Thus the 'stature' achieved by movie stars is unsurprising. It is important to note that when transferred to the domestic television screen a film loses its three most distinguishing characteristics: "size, luminosity, and

93 Roland Barthes discusses the effects of 'moviegoing' in his essay "En sortant du cinéma.

Roland Barthes, "En sortant du cinéma." Communications 23: Psvchanalyse et cinéma. Ed. Raymond Bellour, Thierry Kuntzel and Christian Metz. Paris: Le Centre d'Etudes Transdisciplinaires, 1975. 
audience immobility."94 It ceases to be an experience and becomes instead an object. The loss of scale alone is enough to insure this, but in addition there ceases to be that all-important impenetrable darkness. Thus we are no longer taken out of ourselves, but are interrupted constantly by the visual and aural stimulation of our surroundings. So first, and most importantly, film is designed for the large screen. Resnais writes: "With film, I should like to recover without theory or manifesto, the conditions of reading, that is to say the spectator should feel himself alone." 95 It is 'film space' which creates this effect.

Film space consists of "the actual and suggested spatial relations between elements of the film and between film and spectator." 96 According to film theorist F. E.

94 V. I. Pudovkin, "From Film Technique (On Editing)," Film Theory and Criticism: Introductory Readings ed. Gerald Mast and Marshall Cohen (New York: Oxford UP, 1974) 216.

95 Kreidel 69.

96 F.E. Sparshott, "Basic Film Aesthetics," Film Theory and Criticism: Introductory Readings ed. Gerald Mast and Marshall Cohen (New York: Oxford UP, 1974) 214. 
Sparshott :

The director determines the audience's spatial relation to his films, but what he determines remains an imaginary space; we are within the film's space but not a part of its world; we observe from a viewpoint at which we are not situated. ${ }^{97}$

Let us look at how film space is established by the camera, and its impact upon film narrative in the two Resnais films.

In the previous chapter we were introduced to the plots of Hiroshima mon amour and L'Année dernière à Marienbad which I will now enlarge upon. In Marienbad the narrative order is even more fragmented, less straightforward, than in Hiroshima mon amour, but as in Hiroshima the opening shots are ambiguous because they are extreme close-ups, and thus viewers cannot orient themselves in the scene because of a lack of perceptual/visual cues. In Hiroshima, the opening close-up is a static shot, immobile.

\footnotetext{
97 Sparshott 217.
} 
In Marienbad, the camera pans and one sees close-ups of decorative surfaces that pass slowly, while a voice drones on about architectural detail. But the viewer is unable to determine whether he is seeing ceilings, walls, floors, and not being able to orient oneself in space results in a sense of vertigo. Gradually the camera pulls back and descends from what were corridor ceilings to show the highly decorated walls of these same corridors. The pace of the camera is so slow that one has the impression of sleepwalking, or of being trapped in a dream where, heavyfooted, the dreamer can barely put one foot in front of another. Resnais employs close-ups with voice-overs to open both Hiroshima mon amour and L'Année dernière à Marienbad, and the impact on the viewer in both cases is the same, the loss of visual orientation. But after the openings, Resnais chooses to convey the narratives of the two films in distinctly different ways.

All the action of Hiroshima mon amour, although fragmented, is in chronological order, linear with flashback interruptions. The viewer is given all the neccesary cues and images to construct the narrative in 
time: a first night in a hotel room; the light the next morning, a robed figure and coffee; the afternoon followed by loss of light and the arrival of another night. We are also aided in this structuring by the text which informs us through one of the characters that a certain number of years have passed since the war.

* The viewer is given no such temporal clues in Marienbad. In $\underline{L}^{\prime}$ Année dernière à Marienbad, the chronology is deliberately vague; all the action is circular. The viewer is shifted without warning from daylight conversations in the garden to evenings in the ballroom and back to daylight with characters wearing completely different clothing at each shift. There is further confusion in that the scenes shot in the hotel are mostly windowless which leaves the identification of day or night ambiguous. We have no idea how much time has passed and we are given no references as to present, past or imagined events. Our sole tangible anchor in the text is a scrap of conversation where a hotel guest is trying to remember if there was a freeze in the summer of 1928 or 29. Our confusion as to time is fed by images, specifically the 
constant change of costumes and the lack of windows by which to acertain day or night. Even if the scene is shifted back to a prior location, the difference in clothing leads to confusion, and ultimately to anxiety, at our inability to resolve the chronological dilemma. This temporal confusion reinforces the circularity of action in Marienbad. We now move from narrative to image. Image is the means by which this fragmented chronology is conveyed to the viewer.

The 'frame' is a single image on filmstock, as well as being the outer boundary of an image, while a 'shot' is a single uninterrupted filmed action. A series of shots taken at a single location during a brief time-span make up a 'scene,' and a number of scenes form a 'sequence.' How shots, scenes and sequences are joined together to form a coherent whole is called 'editing' and one of the primary tools of the editor is 'montage'. Montage is the production or the joining of a succession of images to illustrate one idea or to make associations between several ideas. Montage can be seen as a linking of pieces into a chain, a joining which presents or promotes certain ideas through proximity. 
At the same time, by cutting out intermediate steps, montage forces the viewer to fill in the blanks, without giving specific clues or instructions on how this is to be accomplished. According to Russian film theorist Vsevolod Pudovkin, montage is a "juxtaposition of scenes and shots, forcing the spectator to make comparisons - the one shot or scene thus strengthening the other."98 Carrière reflects about montage: "Nothing in the history of artistic expression had suggested that such a relationship-byjuxtaposition might ever be possible."99 Resnais makes

- constant use of montage in Hiroshima mon amour and L'Année dernière à Marienbad. In Hiroshima, one obvious example is the image of the dying German soldier attached to the image of the sleeping Japanese lover. In Marienbad, there is a scene where 'A' drops a glass in the ballroom juxtaposed with the fragment of an event in the bedroom. Each of these images says one thing singly and something else when attached to a second image. When the images of the dying

98 Pudovkin, "From Film Technique (On Editing)" 73.

99 Carrière 12 . 
German soldier and the Japanese lover are juxtaposed, the viewer is clued to look for similarities. When the scene of the shattered glass is attached to that of the bedroom scene, the viewer is made aware that something traumatic occurred.

For our purposes, film footage falls into three main categories: fictional, documentary, and cinéma vérité which employs the hand-held camera and grainy black and white film, and which gives the appearance of a documentary to a fictional film. Naturally for both Hiroshima, mon amour and L'Année dernière à Marienbad fictional footage is the primary component. In addition, in Hiroshima, Resnais employs found footage, also known as library or stock footage, in his use of documentary clips of the aftermath of the atomic bomb. Cinéma verité is also seen in Hiroshima in the footage of the actress as a young woman cycling to meet her lover in Nevers. In Marienbad Resnais also makes use of negative images, a technical device where the image looks like a black and white negative.

The found footage at the beginning of Hiroshima shocks 
the viewer who, seeking to be a voyeur at a safe distance, comes to the film expecting a fictional work or at least only a recreation of reality. The film's previously mentioned cinéma verité sequence, set in France, succeeds in squarely locating events depicted in the past as well as immediately distinguishing between geographic locations. In Marienbad, the use of negative images fulfills two purposes: first, the negative image serves to obscure the action, which in Robbe-Grillet's original text was intended to be a rape; and second, the viewer's response to the negative images is one of acute anxiety due to a loss of visual orientation, or visual cues, and thus the ability to 'read' the image. This effect is enhanced by the rapid shift of images and the way the shots are joined.

Resnais's conception of Hiroshima was operatic, and throughout most of the film one has the impression that the main protagonists are singing a duet. However, unlike duets onstage, where the performers are located far from the spectators, practically all the shots of the couple in Hirshima, mon amour are close-ups. This accomplishes two things: first of all, the technique establishes the couple 
in intimate proximity to the viewer, and second, it eliminates all extraneous visual distractions. We do not really notice the contents of the hotel room, nor even actually see the bathroorn. We see the entrance to the architect's home, but not the intimate rooms of the house. In some strange way the close-ups establish intimacy, but at the same time they create a private realm the viewer is not allowed to penetrate.

Deep-focus shots became popularized by new wave filmmakers. In Hiroshima mon amour there are only two deepfocus shots: the scene on the balcony outside the hotel room and the scene in the last bar. The balcony scene locates the protagonists concretely at a specific geographical site, Hiroshima, and the scene at the bar, the second deep-focus shot, evokes an enormous sense of isolation and desolation. The stark lighting of this second shot also greatly contributes to this effect. By contrast, f in L'Année dernière à Marienbad, the majority of shots are deep-focus and a number of these employ a stationary camera. Deep-focus shots in Marienbad include views of the garden and the cavernous interior of the hotel. As in 
Hiroshima, Resnais again employs deep-focus shots to create a sense of isolation, but the stillness and length of many of these shots also evokes the idea of a place frozen in time, of death or the stillness of remembered images or dreams. There are very few close-ups in Marienbad and those that do exist show the woman and her seducer, the woman and her protector, or one of the three main characters alone. Both Hiroshima, mon amour and L'Année dernière à Marienbad simultaneously tell easily understandable stories but at the same time they interpose between the stories and their perception cinematic devices which are resistant to linear narration. Such devices as jump cuts and montage, flashback and shifts in narration, and interior monologue create perceptual difficulties for the viewer because many of these shifts are made without traditional cueing. These difficulties or barriers to traditional perception and cueing force active, creative participation by the viewer rather than the passive consumption of a product.

Resnais's awareness of the importance of montage and editing in general began at an early age. In an interview for "Image et Son" in February of 1968, Resnais stated that 
one of his early important influences as an editor was the comics.

$$
\begin{aligned}
& \text { Ce que je sais au cinéma, je l'ai autant appris } \\
& \text { par les comics que par le cinéma. Les régles du } \\
& \text { découpage et du montage sont les mêmes dans les } \\
& \text { comics qu'au cinéma. }{ }^{100}
\end{aligned}
$$

One can see the influence of the early exposure to comics in Resnais's work. Something comparable to the deep-focus shots in his films exists in the comics, his use of montage is there, and one also finds the close-up, the closely cropped views of faces and bodies, in both forms. The full human figure is often seen in the comics, and although Resnais rarely employs the entire human figure in Hiroshima mon amour he does so constantly in L'Année dernière à Marienbad. Another distinction is that Hiroshima relies almost exclusively on montage while Marienbad makes use of mise en scène as well. How a film is shot is important, but ultimately the success of a film, as a work of art and as a vehicle for conveying meaning, depends upon editing.

100 René Prédal, Alain Resnais (Paris: Minard, 1968) 7. 
"Of all the technical properties of film the most general and indispensable is editing."101 Resnais originally trained as an editor and his skill in this respect is such that he is often called upon to edit the films of other directors. That he can edit his own films gives him an enormous amount of control over the final product. I have already spoken of editing as a tool to force viewer participation and montage in particular as a way of juxtaposing ideas by way of image. The editor "unites and compresses separate elements... the possibility of eliminating points of passage and interval."102 Editing can compress the narrative, compressing time in such a way that the audience can experience the passage of days, weeks, years in a few hours. Editing can project the viewer into the past or into the imagination of a character. We can follow several story lines at a time, which can be occurring not only at different periods of time, but in

101 Kracauer 29.

102 V.I. Pudovkin, "The Plastic Material." Film: A Montage of Theories ed. MacCann, Richard Dyer (New York: E. P. Dutton, 1966) 30 . 
different locations. Film time, which is not the real time that takes place before the camera, is "conditioned only by the speed of perception and controlled by the number and duration of the separate elements selected for filmic representation of the action."103 In Hiroshima mon amour, editing is used to compress two days into a few hours, and we simultaneously experience the 'present' in Hiroshima and the 'past' in France. In L'Année dernière à Marienbad, through editing, we inhabit possibly the past, the present and the realm of the imagination simultaneously. André Malraux wrote in The Dsychology of the Cinema that editing constitutes the birth of the film as an art: "editing is what truly distinguishes it from simple animated photography and makes it a language."104 In film editing reinforces narration.

Resnais employs a shifting narrator. In Hiroshima, mon amour, the narrator throughout most of the film is the main

103 Pudovkin "The Plastic Material" 30.

104 André Bazin, "The Evolution of Film Language," The New Wave ed. Peter Graham. (New York: Doubleday, 1968) 26. 
character, with the camera as witness. That is to say, the camera and the viewer see the character, the actress, telling the story. There are three scenes in Hiroshima where the camera becomes the narrator: during the documentary footage at the beginning of the film, during the flashback footage situated in Nevers and during one of the two street. scenes where incantatory phrases are employed. In the opening 'duet' the French actress repeats variations of "J'ai tout vu. Tout,"105 while her Japanese lover repeats variations of "Tu n'a rien vu à Hiroshima. Rien."106 Other than some of the Hiroshima footage in the beginning of the film, this one street scene is the only other scene devoid of human iife. This scene features empty streets flanked by buildings on both sides. The actress' voice is still used in the scene, joined by the voice of her Japanese lover, a duet voiced over the images of Hiroshima. Like a newsreel, the actress seems to be picturing the images in her mind as she and her lover speak

105 Duras, Hiroshima mon amour 22.

106 Duras, Hiroshima mon amour 22. 
of them. During the time that the flashbacks in Nevers are actually on the screen, there is silence, and that too is like a newsreel. Here the narration is accomplished solely by the sequencing of images. In Hiroshima it seems as if the protagonist is watching her young self in her mind's eye and her description enables her lover to picture her as well. All the Nevers footage, as well as the empty street scenes, move at a much faster pace than the scenes supposedly shot in the present. The pace and the fragmentation accurately represent how images and thoughts race through the brain - les images-pensées.

In L'Année dernière à Marienbad Resnais also employs a shifting narrator. Unlike in Hiroshima mon amour, it is the camera that is most cften the narrator, and when it is not the camera, it is the seducer who narrates and the camera that witnesses. In both films Resnais also employs what is called the 'subjective camera,' that is to say the camera as witness to what is going on inside the protagonist's mind. The camera as narrator and as witness, the subjective camera and the protagonist as narrator correspond to three textual possibilities for spoken 
narration: the camera as narrator is the voice-over, the subjective camera is interior monologue and the character as narrator is spoken dialogue.

In L'Année dernière à Marienbad, the opening scenes in the vacant corridors greatly resemble the empty street scenes in Hiroshima mon amour. It seems that in the later corridor scenes the movement and pace of the camera are exactly the same as in the street scenes in Hiroshima, and for the same reasons. In these two scenes the rapid forward motion of the camera can be construed as someone running. In Hiroshima, Resnais makes reference to two rivers, the Ota in Japan and the Loire in France, and these empty street and corridor scenes in the two films can also be construed as the movement of water racing down a corridor a flood, a river. In both films, the rapid, flowing camera movement plus the incantatory language ("Tu me tues. Tu me fais du bien."107) create a physicality, the profound impression of something or someone racing toward or from something, or both occurring simultaneously: "... rivers at

107 Duras, Hiroshima mon amour 35 . 
once stationary and moving, recalling the idea of 'movement that goes nowhere'."ios The images of rivers recall both beauty and death: the dead German lover lying next to the Loire, and the ota contaminated by radiation, carrying contaminated fish.

Just as Hiroshima mon amour and L'Année dernière à Marienbad can be broken down into close-ups and deep-focus shots technically, so can they be broken down into roughly two types of space. These two types, public space and private space, are used as a structural device within the films. In Hiroshima, the hotel room and the Japanese architect's home are private space, while the streets, bars and bus station are public space. Even though, descriptively, public and private space can be distinguished from one another in the film by the viewer, the lovers themselves make littie distinction between the two, and their behavior does not seem to alter appreciably whether in supposedly public or private space. It is as if they do not really notice the difference. Historian Marie- 
Claire Ropars-Wuilleumier says of Hiroshima that its "modernity comes, first, from its refusal to separate the political and the aesthetic, the private from the public, the world-wide cataclysm and the individual trauma."109 In L'Année dernière à Marienbad there is also a distinction between public and private space, but in this film, some of the characters hold to the distinction and others ignore it or are as unaware of it as are the protagonists in Hiroshima. One notes that it is the female characters in Marienbad who seek to maintain the boundaries between public and private space and it is the male characters who endeavor to destroy or to ignore these distinctions. Despite the use in both films of public and private space, the level of intimacy available to the viewer in these two films differs. Part of the reason for this is the existence or lack of a substantial sub-text.

Appearing in the text following the screenplay of Hiroshima mon amour are thirty pages of appendices, which

109 Marie-Claire Ropars-Wuilleumier, "How history begets meaning: Alain Resnais' Hiroshima mon amour," French Film ed. Susan Hayward and Ginnette Vincendeau. (London: Rouledge, 1990) 174. 
give the history of what takes place in Nevers, including the name of the actress, details of her family, her German lover and the town. Very little of this information appears in the film, but its existence provides a substructure of information, a history and an existence outside the film which enriches the final product. For example, when you meet someone for the first time, that person has a complete history, whether you are aware of it or not. This history is what creates the person, and during that first encounter you may get a sense of a depth of character, but very few details of the life which created those qualities. The existence of a written history of the actress as a part of the text for Hiroshima gave the character a reality for the creators of the film, which translates to an authenticity and a depth of character which would otherwise be lacking. By contrast, Robbe-Grillet's text offers numerous additional suggestions for music, sound, lighting and camera angle, but gives no reference to character, and the characters remain flat. Resnais carefully reinforces image with sound; places, characters and events may all have individual musical themes and text is repeated to enhance 
meaning.

Noted film theorist Sigfried Kracauer says of sound: "A sound may belong to the world of the film (e.g. the dialogue of the characters) or it may be extraneous (e.g. background music or a commentary)."110 Conventionally, either image or text is generally given pride of place depending on the preferences or prejudices of the individual director. Sound, which in this case refers to music, not dialogue, usually comes in a poor third, but Resnais considers all three elements equally when constructing a film, and often it is sound, in the form of music, which informs his other choices. It is also sound that attracted Alain Robbe-Grillet to the medium, particularly: "the possibilities that sound offered in subverting conventional reality and depicting the imaginary and the subjective by acting simultaneously on the senses of sight and hearing."111 For Resnais, music is the fundamental element; he does not consider it as an

\footnotetext{
110 Sparshott 224 .

111 Fragola and Smith 3.
} 
accompaniment. Resnais speaks of the relationship of music in his films: "La multiplicité des plans obligeait à donner à la musique une importance préponderante. Elle n'était plus la pour 'accompagner' les images, mais pour créer l'ossature du film..."1i2

Thus Resnais also often conceives of his films musically, both in terms of genre and organization. Music is often his first concern or conception, rather than the afterthought it is for so many films. He envisioned Hiroshima, mon amour as opera and "Resnais a appelé plusieurs fois 'L'Année dernière à Marienbad' une comédie musicale sans chanson."113 Later he spoke of this again in an article in "France-Observateur" May 19, 1961:

Il y a dans Marienbad une structure de poème musical, une valeur incantatoire du texte qui se répète, un ton de recitatif qui correspond à l'Opéra. A tout instant on a l'impression que les personnages pourraient s'arrêter de parler et

\footnotetext{
112 René Prédal, Alain Resnais 34-35.

113 René Prédal, Alain Resnais 30.
} 
continuer leur text en chantant. ${ }^{114}$

Resnais employs music as an integral part of film structure, rather than as an afterthought.

Like sound in general, film music takes two forms: local music, which occurs in the scene itself, and background music, which functions much like narration. Background music tells us how to respond to a film's visual cues, establishes and maintains moods, provides a sense of place, signals the passage of time, and anticipates what is to come by echoing cues of foreboding or romance. In Hiroshima, mon amour there is a musical theme for each town, one for Hiroshima and one for Nevers. These musical themes occur whenever the towns are discussed, and also precede film footage or flashbacks. In so doing, they offer clues to the viewer, give the individual a means of ordering and making sense of the film's progression, and also provide a sense of what emotions are connected with each location. The theme for Hiroshima is measured, stately, serious, slightly ominous and modern. The theme 
for Nevers is at once young, sad, nostalgic, sweet, pensive, and hopeful. There is also a theme for the initial film footage of the aftermath of the bomb, the ruins, the museum, which is pulsing and lively, and lyrical with a hint of ragtime. This is one use of music, which has a narrative quality of its own, like a musical voice-over. The gaiety of the theme used during the museum footage, contrasted with the grim nature of the images and text being presented, adds to the horror by giving the initial impression, musically, that this will be a pleasant experience.

Music also appears as sound that is an integral part of a particular scene. For example, during the parade that is being filmed, there is an insistent traditional Japanese song that is played, and later in the bar a typical melody of prewar France is played on the jukebox. This music also can be used as commentary, to aid the director in making a point. The French song recalls days of innocent youth, prewar France, and helps set the emotional climate in the scene that is taking place.

Music has another role entirely in L'Année dernière à 
Marienbad. Other than two brief symphonic pieces during the opening credits and at one other point on the film, the musical score consists entirely of an organ recital. Initially it drowns out the narration, and it is always bombastic, overblown and loud, which in many ways is a perfect metaphor for the film itself. The music also reinforces the lack of reality in the film and the incongruity between image and narrative as when, during the concert, the viewer sees two violins being played, but hears only organ music. The sparing use of symphonic pieces in this film heightens mood, cues the audience of an upcoming event and increases a sense of foreboding.

Ultimately Resnais's filins owe more structurally to music than to theater or to literature. He uses music as a basis for his films. For Resnais, a film is like a series of études which express a number of ideas and which can be viewed from a variety of angles, with each successive angle deepening the meaning, multiplying the possible ways for comprehending the film. When cinematography is thus wedded to musical structures, we see it from a fresh perspective, and the musical structure achieves a new and different 
status within the context of sound. Like montage, with image juxtaposed to image to create or enhance meanings or associations, music can, within the context of sound, also be used to enhance associations or meanings. Concerning this relationship between music and film, director Ingmar Bergman stated:

I would say that there is no art form that has so much in common with film as music. Both affect our emotions directly, not via the intellect. And film is mainly rhythm; it is inhalation and exhalation in continuous sequence... I often experience a film or play musically. ${ }^{115}$

Besides music as sound, there is also voice.

The purposes to which Resnais employs voices in his films are many. In Hiroshima, mon amour only five Vice characters actually have dialogue: the actress, her lover, the old woman at the train station, the server and the man at the bar. The actress speaks French. The flashbacks are

115 Ingmar Bergman, "Film Has Nothing To Do With Literature," Film: A Montage of Theories, ed. MacCann, Richard Dyer (Nev York: E. P. Dutton, 1966) 144. 
silent, except for a single scream, so we never hear her parents speak French, nor her German lover. Her Japanese lover speaks heavily accented French, and one supposes that her German lover also spoke heavily accented French. So the first words of love she ever heard, the ones that are imprinted forever, were accented. Two forbidden loves, one traitorous, one adulterous, two enemies of France, and two accents to remind her. None of the other characters who speak, speak French, thus they remain outside the charmed circle the lovers have created for themselves. Language is something they alone share, neither the old woman speaking Japanese at the station, nor the server, nor the slick Japanese at the bar speaking English are permitted entry. She only nods to the Engiish speaker's questions. She does not speak.

In addition, there is the hurn of voices during the parade scene and in the first bar. But because it is in Japanese, these incidental voices would seem to a French audience little more than the twittering of birds. There is the sound of traffic during the morning leavetaking, which brings us back to everyday reality, the city, the rhythm of 
daily life, and which breaks the lovers' spell. There is also the voice announcing a departure at the station which prestrer

foreshadows the female protagonist's own departure. The most unusual use of sound is the chorus of frogs, first heard at the bar and then just outside the hotel. The volume of these sounds is very loud, relative to everything else, and at the moment when one hears the frogs there are no other background sounds occurring. It is an odd thing to hear in an urban envirorment and the viewer may remember the opening dialogue and the tale of the appearance of insects two days after the bomb.

So in Hiroshima mon arnour there is music and dialogue and background noises in the form of frogs, traffic noises and Japanese conversation, and there is silence invested with a single scream. The dialogue consists of a conversation between two people, a duet, and in the beginning, like in so many operas, one person says yes, yes, yes and the other no, no, no. But there is also silence in this film, the silence that exists in film which cannot be found in nature: to achieve silence for a film, a film technician must actually record silence, and 
apparently no two silences are exactly alike. For the viewer silence creates or heightens mood. Resnais employs silence in Hiroshima during the flashbacks in Nevers.

In L'Année dernière à Marienbad the use of the human voice is more restricted. The spectator is intended to hear everything that is said even by minor characters. There is no background or incidental sound. Like all other aspects of this film, sound is carefully orchestrated and controlled. In this way it is more like theater than real life. One of the three main protagonists, the narrator ' $x$,' speaks accented French like the Japanese architect in Hiroshima mon amour. In this case the accent is Italian. There is also a single scream in Marienbad when the woman ' $A$ ' drops and shatters her glass at the bar. This scene is inter-cut with scenes in the bedroom which shed light on the reason why she screams and drops her glass. The only sounds which are not music, voice-over or dialogue are gunshots which occur in the shooting gallery and in a single instance in the bedroom. The gunshots emphasize the supressed, latent viclence of the film. Resnais sets up the audience with sound and punctuates his themes with sound. 
Sound, like image, is a mechanical technique used by Resnais to convey meaning. In films, time, which is less tangible than either sound or image, can also be conveyed technically, and at the same time be made more tangible.

In Hiroshima mon amour and L'Année dernière à Marienbad, Resnais approaches time in terms of memory, the function of remembering and forgetting. In Hiroshima, he uses memory as a structure for the organization of the film. Initially, in the opening of Hiroshima, it is remembering the aftermath of the Hiroshima bombing differently that forms the verbal duet between the two lovers, the actress and the architect. This disparity between the two points of view is shown with footage that does not match the dialogue. This is also evident in Marienbad when the verbal description of a room or action does not match the image. For example, during a scene where the narrator ' $\mathrm{X}$ ' says that ' $A$ ' is not approaching walls or mirrors of her room, we, the audience, see her clinging to them. In Hiroshima, the actress refuses or is unable to remember her German lover and yet it is the trauma of his death that has formed her character and her life and 
ultimately leads her to Hiroshima and to her Japanese lover. It is this trauma which allows Resnais to create the flashback footage of Nevers, and it is finally the inevitability of forgetting that provides the ending of the film. In Marienbad it is the inability of the woman ' $A$ ' to remember last year and the efforts of the narrator ' $\mathrm{X}$ ' to force her to remember it in a certain way that is the basis of the film. It is this premise which gives Resnais permission to create and recreate and to join the same scenes in a variety of ways. This repetition is another of Resnais's major structural building blocks.

In L'Année dernière à Marienbad the entire film consists of intensive repetition with variation. We have seen Resnais's use of Freud's theory that the compulsion to repeat is used as a means of mastering difficult material. In Marienbad, each conversation, every subject, all images, are approached again and again from different directions, different angles. Stories, dialogue and image echo each other, foreshadow each other. In Hiroshima, it is basically the language that repeats itself: rhythmically the characters respond to each other using the same structures, 
the same words, and there is the repetition of the voiceover as we see the empty streets: "Tu me tues. Tu me fais du bien." 116 But at a deeper level it is the life of the actress that repeats itself. The death of her German lover, an enemy of France, an impossible love, is repeated in Hiroshima, with a married man, a Japanese, also the enemy during the war. Resnais uses repetition of image in the flashback of Nevers to show the young lovers, always meeting each other or on the way to meet each other. This forms the framework for the film.

Hiroshima mon amour and L'Année dernière à Marienbad are products of modernism. As such the two films exhibit the traits of non-linear narrative development, fragmentation, and unresolved or ambiguous conclusions. In film, these traits are held together with film technology. In Marienbad, the narration and its fragments are held together with two specific cinematographic conventions. First the sound, text or dialogue from the preceeding shot or scene bleeds over into the following shot, such as a

116 Duras, Hiroshima mon amour 35. 
laugh heard in one scene which continues into the next where one can actually see the person laughing, the explanation of a game which begins before we see the person who is explaining or a sentence begun by one character in one scene being finished by another in the following one. 2. Second, foften the narrative voice or the character's voice for a particular scene is not relating what is happening in that scene but instead is telling a story that supposedly already occurred, or in the case of the narrative voice, it is as if the character in the scene is thinking of something that already happened. However, these events which are spoken of, but which we the spectators have not yet seen, will appear later in the film, and will seem familiar to us, because we have already heard them discussed. For example, there is the story of a woman breaking the heel of her shoe in the garden and the detailed discussion of statues in the same garden which are talked of long before they are seen. A third device used effectively to designate change in time and place is the visible change of wardrobe of the female protagonist 'A.' Her change of clothing can confuse the viewer but at the 
same time also cue the viewer to the continuation of an event or action even if the return to the scene occurs some shots or scenes later. These technical conventions link the disparate images through the continuity of sound and time and the repetition of history, and thus give the $V$ viewer a way to make sense of the fragmentation.

In Hiroshima mon amour the continuity is more conventional; day follows night and flashbacks have a different style and quality. The main difference from traditional continuity is the lack of lead-ins to these changes of time and place. It is the viewer who must create the transitions in Hiroshima mon amour, while in L'Année dernière à Marienbad no transitions are possible. As Carrière states:

Writing a story or screenplay means injecting order into this disorder: making a preliminary selection of sounds, actions, and words: discarding most of them, then stressing and reinforcing the material selected. It means violating reality (or at least, what we perceive of reality' to rebuild it in anocher way, 
confining the images within a given frame,

selecting the real -voices, emotions and

sometimes, ideas. ${ }^{117}$

Resnais succeeds with his use of image, sound and text, with his understanding of the possibilities of camera and editing to go beyond the scope of the screenplay, to create a many faceted work, both visually and in terms of ideas. 
CHAPTER VI - CONCLUSION

This thesis has examined how the cinematic organization of film is used to convey meaning. Hiroshima mon amour and L'Année derrière à Marienbad, two films by Alain Resnais, have been used as models for this purpose. Following in the line of Bordwell, this thesis argues for a new type of film criticism, one that recognizes the uniqueness of film by adding technical analysis to the literary methods currently dominating film criticism. It suggests that looking at film in terms of its technology has been overlooked in favor of traditional literary criticism.

In these films, director Alain Resnais employs film technique to convey specific meanings to the viewer. JeanClaude Carrière says of the medium:

Basically a technical process, even a merely mechanical one, cinema has nevertheless explored the most delicate areas, the subtlest shades of feeling. ${ }^{118}$

118 Carrière 146. 
This thesis proposes that the literary methods which are appropriate for literature are inadequate for film, because of the way cinematographic technique is employed to convey meaning. To this end, the films, Hiroshima mon amour and L'Année dernière à Marienbad, are analyzed in terms of technique, how technique structures film, as well as in more traditional terms.

The intent of this thesis is to implement a model for a third sort of film analysis, an alternative to interpretation-driven criticism, one which includes, in addition to explication and interpretation, the use of film technology as a valid means of comprehending a film. The result of this broader form of analysis is a more accurate understanding of film through the comprehension of the aspects which make it an original art form. The use of specific film technology forms a more balanced and accurate approach to film criticism. First, film space is established by the camera. The physical intimacy or distance achieved by the camera in relationship to the viewer is not possible with text alone. The extreme closeups that begin both Hiroshima mon amour and L'Année 
dernière à Marienbad, that disorient and bewilder the viewer, would not have the same effect in text alone, too much description would be needed, and in these scenes, it is the visual impact, the image, that carries the point. Likewise the visceral impact of such jump-cuts as the shift from sleeping Japanese lover to dying German soldier could not occur in a purely literary format. The effect of pacing, rapid camera movement or the shock of the negative images in Marienbad do not exist outside of film technology. And there is nothing in a screenplay that can achieve what Resnais achieved by juxtaposing the images of mutilated children with descriptions of flowers, or lighthearted music with an atomic destruction museum. History is alive in the images of Hiroshima and Nevers. Marguerite Duras said that for her, memory and history are contained in places, that "seeing the place that carries the trace or mark of the past thus becomes equated with recovering the past."119 There is an impact on the senses and the emotions made by image and sound. As Bergman said: "there is no art 
form that has so much in common with film as music. Both affect our emotions directly, not via the intellect."

Resnais's films are put together achronologically. Thus the viewer is forced to consider structure rather than narrative: structure as consisting of image and camera work, specific use of the camera in terms of space and spatial relationship, and the camera as narrator. The importance of editing and montage are also discussed. Next, the discussion of structure moves to the films' texts and sub-texts, which are focused on dialogue, description, voice-over and interior monologue. In this vein, the thesis examines the texts as modernist works. The same modernist trends seen in the texts are present in the films' use of non-linear narrative, unexplained events, lack of conclusion or moral jidgment, the use of poetic narrative, and increased viewer participation or responsibility. Resnais depersonalizes himself and his role in the film, in order to make the film more personal for the spectator. It is this approach which gives his films their mystery, 
privacy and clarity. ${ }^{120}$ we see, established from the opening shots of both films, the fragmentation and disjunction that work against narrative unity. Third, sound is analyzed, including voices, music, sound effects and silence. For Resnais, music is the unifying element of a film. It is the "soundtrack that spirally holds the film together."121

"Memory, like sight, is a matter of separation, of differentiation. We really remember only what we have singled out."122 The focus then shifts to time as observed in the films, including memory, remembering and forgetting, real time, flashback and imaginary scenes. The differences between novels and films is evident in "time, tempo, space and angle of approach (point de vue)."123 Carrière states: "Like every other human activity, cinema is inextricably locked into time."124 There are several ways of looking at this statement. One way, of course, is the fact that film

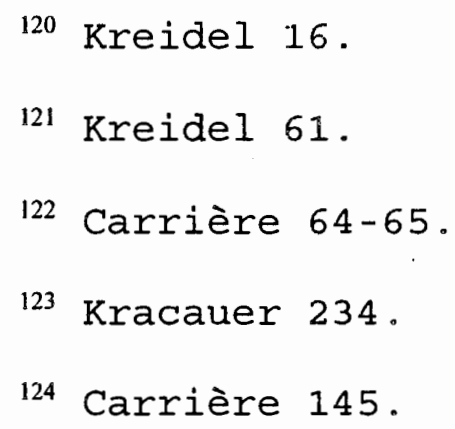


footage has a determined length or duration in time. Film time is "conditioned only by the speed of perception and controlled by the number and duration of the separate elements selected for filmic representation of the action." ${ }^{125}$ Another is that film represents and is a product of its time. It exists in the time in which is made, and that time frame, that place in history affects its style, content, technology, politics and its reception by the audience.

Every action takes place not only in time, but also in space. Filmic time is distinguished from actual in that it is dependent only on the lengths of the separate pieces of celluloid joined together by the director. ${ }^{126}$

Finally, the role of repetition as a structuring mechanism is examined in both films. This proposed method of technical analysis also includes the art-historical context. The art-historical context of a film is important

125 Pudovkin, "The Piastic Material" 30.

126 Pudovkin "The Plastic Material" 30. 
not only in terms of the evolution of film technique but also of the evolution of the visual acumen of the viewer. The filmscripts themselves are also examined to determine their influence on the final product, with the conclusion that, at least in Resnais's case, the script is the starting point: "screen plays are... not complete works in themselves; they are blueprints of projected films."127 Even the most insightful, accurate literary analysis of a film would be incomplete without the emotional and cognitive effects of film technology.

In the screenplay the requisite disappearance of the skeleton of the story, the erasure of visible effects, has only one goal: to transform invention into apparent reality. ${ }^{128}$

What all Resnais's efforts amount to is "an attempt to make the invisible visible."129 In other words, Resnais

127 Dudley Nichols, "The Writer and the Film." Film: A Montage of Theories ed. MacCann, Richard Dyer (New York: E. P. Dutton, 1966) 82 .
128 Carrière 171.
129 Carrière 27-28. 
takes image, text and sound and creates more than the sum total of these three elements. He conveys meaning. Resnais creates not images of reality but rather, images of thoughts. He employs film as a painter employs paint, manipulating the medium to achieve his ends. His creative source is his technical expertise and his intuitive approach .

His films are based on how he forces themes onto - plots. He selects a writer to give him a screenplay. He then forces his own theme on the screenplay. The film that results confirms that it is Resnais' theme and not the screenplay that he wishes to convey, and this is borne out by the way he shoots and edits the film. None of Resnais' films retain even half the intent of the original screenplay. The screenplays exist to provide a basis for Resnais' work; they are tools, means to an end. ${ }^{130}$

What director Luiz Bunuel says on film seems to mirror

130 Kreidel 14. 
Resnais's attitudes as well.

Bunuel often said that films should be like cathedrals. The authors' names should be removed from the credits, leaving just a few anonymous reels, pure, free of any trace of their creator. Then we would watch them the way we enter a cathedral, not knowing the names of those who built it, or even the master builder. ${ }^{131}$

Film is a medium that engages the viewer in a very primal way; watching a film is a visceral experience, where not only the intellect, but the emotions are involved. Carrière expresses it this way: "But what I call the 'meat of the film' is located beyond words and images, in the indefinable realm of feeling." ${ }^{132}$ He continues:

The true question is not 'What is the meaning of this story? In how many ways ought I to understand it? Can it be reduced to a single meaning?' The question is 'Can this person I am

131 Carrière 176.

132 Carrière 171. 
speaking to profit from what I am about to tell

$\underline{h i m}^{133}$

Resnais succeeds in conveying meaning through cinematic organization, not a "single meaning," or a simple one, but meaning built of layers of image, sound and text, meaning conveyed through time, meaning situated in the particular context of the movie theatre, meaning that the viewer determines individually through his own efforts. 
BIBLIOGRAPHY

Agee, James. Agee on Film. New York: McDowell, Obolensky, 1958.

Alter, Jean V. "Alain Robbe-Grillet and the cinematographic style." Modern Language Journal 48 (1964): 363-366.

Armes, Roy. The films of Alain Robbe-Grillet. Philadelphia: John Benjamins North America, 1981.

Astruc, Alexandre. "The Birth of a New Avant-Garde: La caméra-stylo." The New Wave. ed. Peter Graham. New York: Doubleday, 1968. 17-23.

Austin, Guy. Contemporary French Cinema. New York: Manchester UP, 1996.

Barthes, Roland. "Alain Robbe-Grillet." Evergreen Review $2.5(1959): 113-126$.

--- En sortant du cinéma." Communications 23: Psychanalyse et cinéma. ed. Raymond Bellour, Thierry Kuntzel and Christian Metz. Paris: Le Centre d'Etudes Transdisciplinaires, 1975. 104-107.

Bazin, André. "La Politique des Auteurs." The New Wave. ed. Peter Graham. New York: Doubleday, 1968. 137-155. -.-. "The Evolution of Film Language." The New Wave. ed. 
Peter Graham. New York: Doubleday, 1968. 25-51.

--. What is Cinema?. trans. and ed. Hugh Gray. Berkeley: U of California P, 1967.

Beja, Morris. "Last Year at Marienbad." Film and Literature: An Introduction. New York: Longman, 1979. $225-234$.

Bergman, Ingmar. "Film Has Nothing To Do With Literature." Film: A Montage of Theories. ed. MacCann, Richard Dyer. New York: E. P. Dutton, 1966. 142-146.

Bluestone, George. "Novels into Film." Film: A Montage of Theories. ed. MacCann, Richard Dyer. New York: E. P. Dutton, 1966. 132-141.

Bordwell, David. Making Meaning: Influence and Rhetoric in the Interpretation of Cinema. Cambridge: Harvard UP, 1989.

-.. Narration in the Fiction Film. Madison: $U$ of Wisconsin P, 1985 .

Cantor, Jay. "Death and Image." Triquarterly 79 (1990): $173-158$.

Carrière, Jean-Claude. The secret Language of Films. Trans. Jeremy Leggatt. New Yoik: Pantheon Books, 1994. 
Cohen, Keith. Film and Fiction: The Dynamics of Exchange.

New Haven: Yale UP, 1979.

-.-. "Pleasures of Voicing: Oral Intermittances in Two Films by Alain Resnais." L'Esprit Créateur 30.2 $(1990): 58-67$.

-Colpi, Henri. "Editing Hiroshima Mon Amour." Sight and Sound $29.1(1959-60): 14-16$.

Clair, René. "The Art of Sound." Film: A Montage of

Theories. ed. MacCann, Richard Dyer. New York: E. P. Dutton, 1966. 38-44.

Clerc, Jeanne-Marie. "Marguerite Duras, collaboratrice d'A. Resnais, et le rapport des images et des mots dans les textes hybrides." Revue des Sciences Humaines 73.202 (1986): $103-116$

Davis, Doris McGinty. "Le Voyeur et L'Anné dernière Marienbad." French Review 38 (1965): 477-484.

Domarchi, Jean, Jacques Doniol-Valcroze, Jean-Luc Godard, Pierre Kast, Jacques Rovette and Eric Rohmer. "Hiroshima, notre amour." Cahiers du Cinéma: The 1950s: Neo-Realism, Hollywoood, New Wave. ed. Jim Hillier. Cambridge: Harvard UP, 1985. 59-70. 
Duras, Marguerite. Hiroshima mon amour. France: Gallimard, 1960.

-.- Hiroshima mon amour. trans. Richard Seaver. London: Calder and Boyars, 1966.

Duras, Marguerite, and Xavire Gautier. Woman to Woman. Trans. Katherine A. Jensen. Lincoln: U of Nebraska P, 1987.

Earle, William. "Revolt Against Realism in the Films." ed. Mast, Gerald and Marshall Cohen. Film Theory and Criticism: Introductory Readings. New York: Oxford UP, 1974. $32-42$.

Eisenstein, Sergei. "Collision of Ideas." Film: A

Montage of Theories, ed. MacCann, Richard Dyer. New York: E. P. Dutton, 1966. 34-37.

-.. Film Essays and a Lecture. ed. Jay Leyda. Princeton: Princeton UP, 1968 ,

--- Film Form. Trans. Jay Leyda. New York: Harcourt, Brace and World, 1949.

Fellini, Frederico. "The Road Beyond Neorealism." Film: A Montage of Theories. ed. MacCann, Richard Dyer. New York: E. P. Dutton, 1966. 377-384. 
Fragola, Anthony N. and Roch C. Smith. The Erotic Dream Machine. Carbondale: Southern Illinois UP, 1992.

Frodon, Jean-Michel. L'age moderne du cinéma français. France: Flammarion, 1995.

Higgins, Lynn A. New Novel, New Wave, New Politics:

Fiction and Representation of History in Postwar

France. Lincoln: U of Nebraska P, 1996.

Irwin, Alec. "The French Connection." Village Voice 34.16 (1989): 66 .

Ishagpour, Youssef. Le cinéma. France: Flammarion, 1996. Jinks, William. The Celluloid Literature: Film in the

Humanities. 2nd ed. Beverly Hills: Glencoe, 1974. Kawin, Bruce F. Telling it Again and Again: Repetition in Literature and Film. Ithaca: Cornell UP, 1972.

Kline, T. Jefferson. "Rebecca's Bad Dream: Speculations on/in Resnais's Marienbad." Screening the Text: Intertextuality in New wave French Cinema. Baltimore: The Johns Hopkins UP, 1992. 54-86.

Kracauer, Siegfried. Theory of Film: The Redemption of Physical Reality. New York: Oxford UP. 1960. Kreidel, John Francis. Alain Resnais. Boston: Twayne, 1977. 
Kristeva, Julia. The Pain and Sorrow in the Modern World: The Works of Marguerite Duras. PMLA 102.2 (1987): $138-152$.

Labarthe, André S. "Marienbad Year Zero." Cahiers du Cinéma: 1960-1968: New Wave. New Cinema.

Reevaluating Hollywood. ed. Jim Hillier. Cambridge: Harvard UP, 1986. 54-58.

Lane, Nancy. "The Subject in/of History." Literature and Film in the Historical Dimension. ed. John D.Simmons. Gainesville: U of Florida, 1994. 89-100.

Lapsley, Robert and Michael Westlake. "Authorship." Film Theory: an Introduction. Manchester: Manchester UP, 1988. 105-128.

Luccioni, Gennie. "Marguerite Duras et le roman abstrait." Esprit 26 (1958): 73-76.

Marcorelles, Louis. "Rebel with a Camera." Sight and Sound $29.1(1959-50): 12-14$.

McGlynn, Paul. "Last Year at Marienbad: The Aesthetics of Perhaps." University of Windsor Review 16.1 (1981): $5-12$.

Medhurst, Martin J. "Hiroshima, Mon Amour: From 
Iconography to Rhetoric." The Ouarterly Journal of Speech 68.4 (1982): $345-370$.

Michalczyk, John J. "Alain Robbe-Grillet." The French Literary Filmmakers. London: Associated University Presses, 1980. 97-118.

-.-."Marguerite Duras." The French Literary Filmmakers. London: Associated University Presses, 1980. 119-140. Monaco, James. How to Read a Film: The Art. Technology, language, History and Theory of Film and Media. Rev. ed. Oxford: Oxford UP, 1981.

Morrissette, Bruce. "The New Novel in France." Chicago Review $15.3(1962)^{\circ}: 1-19$.

-.-. "New Structure in the Novel: Jealousy, by Alain Robbe-Grillet." Evergreen Review 3.10 (1959): 103-107, $164-190$.

Moses, John W. "Vision Denied in Night and Fog and Hiroshima, Mon Amour." Literature/Film Quarterly 15.3 (1987): 159-163.

Nichols, Dudley. "The Writer and the Film." Film: A Montage of Theories. ed. MacCann, Richard Dyer. New York: E. P. Dutton, 1966. 73-87. 
Prédal, René. Alain Resnais. Paris: Minard, 1968.

Pudovkin, V. I. "From Fj.lm Technique (On Editing)." Film Theory and Criticism: Introductory Readings. ed. Gerald Mast and Marshall Cohen. New York: Oxford UP, 1974. 67-74. --. "The Plastic Material." Eilm: A Montage of Theories. ed. MacCann, Richard Dyer. New York: E. P. Dutton, 1966. 23-33.

Purdy, Strother B. "Gertrude Stein at Marienbad." PMLA 85.5 $(1970): 1096-1095$

Ramsey, Raylene L. "The Sado-Masochism of Representation in French Texts of Modernity: The Power of the Erotic and the Eroticiization of Power in the work of Marguerite Duras and Alain Robbe-Grillet." Literature and Psychology 37.3 (1991): 18-28.

Ricardou, Jean. Le nouveau roman. Paris: Ecrivains de Toujours/Seuil, 1978.

-.- Problèmes du nouveau roman. Paris: Editions du Seuil, 1967.

Richardson, Robert. Literature and Film. Blomington: U of Indiana P, 1969.

Robbe-Grillet, Alain. For a New Novel. Trans. Richard 
Howard. Evanston: Northwestern UP, 1989.

-.-. L'Année dernière à Marienbad. Paris: Les Editions de Minuit, 1961.

-.-."L'Année dernière à Marienbad." Sight and Sound 30.4 (1961): $176-179$.

-.-. Last Year at Marienbad. Trans. Richard Howard. New York: Grove, 1962.

Ropars-Wuilleumier, Marie-Claire. "How history begets meaning: Alain Resnais' Hiroshima mon amour." French Film. ed. Susan Hayward and Ginnette Vincendeau. London: Rouledge, 1990.

Roud, Richard. "Conversations with Marguerite Duras." Sight and sound $29.1(1959-60): 16-17$.

Sarris, Andrew. "Notes on the Auteur Theory in 1962." Perspectives on the study of Film. ed. John Stuart Katz. Boston: Little Brown and Company, 1971. 500-515. Shoos, Diane. "Sexual Difference and Enunciation: Resnais"s Last Year at Marienbad." Literature and Psychology 34.4 (1988): $1-15$.

Sontag, Susan. "Against Interpretation." The Rhetoric of Film. ed. John Harrington. New York: Holt, Rinehart 
and Winston, 1973. 355-364.

Sparshott, F. E. "Basic Film Aesthetics."Film Theory and Criticism: Introductory Readings. ed. Gerald Mast and Marshall Cohen. New York: Oxford University Press, 1974. 209-232.

Stoltzfuz, Ben. "Robbe-Grillet et le Bon Dieu." L'Esprit Créateur 8 (1968): $302-311$.

Sturrock, John. "Alain Robbe-Grillet." The New French

Novel. London: Oxford UP, 1969.

Suleiman, Susan Rubin. Subversive Intent: Gender, Politics and the Avant-Garde. Cambridge: Harvard UP, 1990. Thiher, Allen. The Cinematic Muse: Critical Studies in the History French Cinema. Columbia: U of Missouri P, 1979.

Thompson, Kristin anà David Bordwell. Film History: An Introduction. New York: McGraw-Hill, 1976.

Vorkapich, Slavko. "Toward True Cinema." Film: A Montage of Theories. ed. MacCann, Richard Dyer. New York: E. P. Dutton, 1966. 171-179.

Willis, Sharon. Marquerite Duras, writing on the Body. Urbana: U of Illinois P, 1987. 
Wollen, Peter. "From Signs and Meanings in the Cinema: The Auteur Theory." Film Theory and Criticism:

Introductory Readings. ed. Gerald Mast and Marshall Cohen. New York: Oxford UP, 1974. 530-540.

Wynne-Davies, Marion. ed. The Bloomsbury Guide to English

Literature. New York: Prentice Hall General Reference, 1990. 
FILMOGRAPHY

Hiroshima mon amour. Dir. Alain Resnais. Screenplay by Marguerite Duras. Argo.Films, 1959.

L'Année dernière à Marienbad. Dir. Alain Resnais. Screenplay by Alain Robbe-Grillet. 1961. Connnoisseur Video Collection, 1990. 